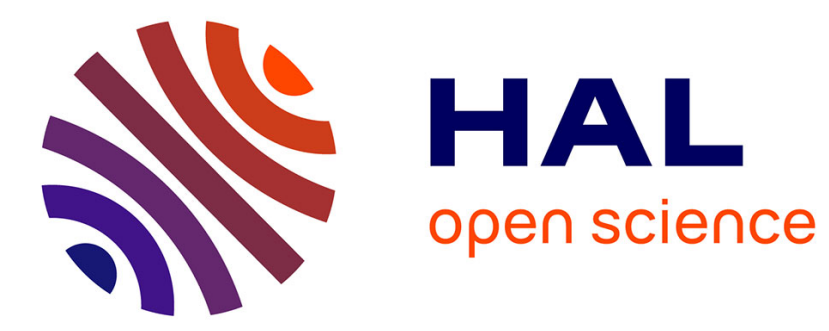

\title{
Where does profit sharing work best? A meta-analysis on the role of unions, culture, and values
}

\author{
Hristos Doucouliagos, Patrice Laroche, Douglas L Kruse, T D Stanley
}

\section{To cite this version:}

Hristos Doucouliagos, Patrice Laroche, Douglas L Kruse, T D Stanley. Where does profit sharing work best? A meta-analysis on the role of unions, culture, and values. 2018. hal-03048678

\section{HAL Id: hal-03048678 \\ https://hal.science/hal-03048678}

Submitted on 9 Dec 2020

HAL is a multi-disciplinary open access archive for the deposit and dissemination of scientific research documents, whether they are published or not. The documents may come from teaching and research institutions in France or abroad, or from public or private research centers.
L'archive ouverte pluridisciplinaire HAL, est destinée au dépôt et à la diffusion de documents scientifiques de niveau recherche, publiés ou non, émanant des établissements d'enseignement et de recherche français ou étrangers, des laboratoires publics ou privés. 


\section{Z A Institute of Labor Economics}

\section{DISCUSSION PAPER SERIES}

IZA DP No. 11617

\section{Where Does Profit Sharing Work Best?} A Meta-Analysis on the Role of Unions, Culture, and Values

Hristos Doucouliagos

Patrice Laroche

Douglas L. Kruse

T.D. Stanley 


\section{Z A Institute of Labor Economics}

Initiated by Deutsche Post Foundation

\section{DISCUSSION PAPER SERIES}

IZA DP No. 11617

\section{Where Does Profit Sharing Work Best? A Meta-Analysis on the Role of Unions, Culture, and Values}

\section{Hristos Doucouliagos}

DeLMAR, Deakin University and IZA

Patrice Laroche

Université de Lorraine

\section{Douglas L. Kruse}

Rutgers University and IZA

\author{
T.D. Stanley
}

DeLMAR, Deakin University

Any opinions expressed in this paper are those of the author(s) and not those of IZA. Research published in this series may include views on policy, but IZA takes no institutional policy positions. The IZA research network is committed to the IZA Guiding Principles of Research Integrity.

The IZA Institute of Labor Economics is an independent economic research institute that conducts research in labor economics and offers evidence-based policy advice on labor market issues. Supported by the Deutsche Post Foundation, IZA runs the world's largest network of economists, whose research aims to provide answers to the global labor market challenges of our time. Our key objective is to build bridges between academic research, policymakers and society.

IZA Discussion Papers often represent preliminary work and are circulated to encourage discussion. Citation of such a paper should account for its provisional character. A revised version may be available directly from the author. 


\section{ABSTRACT}

\section{Where Does Profit Sharing Work Best? A Meta-Analysis on the Role of Unions, Culture, and Values}

In this article we re-examine the relationship between group-based profit sharing and productivity. Our meta-regression analysis of 313 estimates from 56 studies controls for publication selection and misspecification biases and investigates the impact of firm level unionisation and national differences in values and culture. Profit sharing is positively related to productivity on average, with a stronger relationship where there is higher unionisation and in countries where honesty is less highly valued and there are higher levels of individualism. The latter two results suggest profit sharing works best in settings where cooperation does not naturally occur. The positive effect of profit sharing on productivity is larger in cooperative firms and in transition economies.

JEL Classification: $\quad$ J33, J51, J54, M52

Keywords: $\quad$ profit sharing, productivity, meta-regression analysis, unions, tax evasion, individualism

Corresponding author:

Hristos Doucouliagos

Department of Economics

Deakin Business School

Deakin University

70 Elgar Road

Burwood, Vic 3125

Australia

E-mail: chris.doucouliagos@deakin.edu.au 


\section{Introduction}

"The economists' tool of a "production function" cannot be defined independently of workers' morale, attitudes, and wage rates .... Workers may produce more effectively and may promote the profitability of the firm if they have a sense of financial incentive and profit reward when the corporation flourishes."

Samuelson (1986, p. 959)

Profit-sharing schemes, which directly link employee compensation to firm profits, have grown rapidly in recent decades, now covering about one-third of U.S. workers and between $14 \%$ and $60 \%$ of workers across European countries (Blasi et al., 2014: 113). ${ }^{1}$ The proportion of firms offering profit sharing has increased since 2000 (Hashi and Hashani, 2013). The empirical evidence on their effects provides a wide range of estimates, and debate about the impact of profit sharing on employee attitudes (Coyle-Shapiro et al., 2002; Heywood et al., 2005) and productivity continues (Blinder, 2011; Blasi et al., 2016). While the majority of studies find a positive relationship between profit sharing and productivity, there is much variation in the effects of profit sharing, and many studies find little or no improvement in productivity. Of the 313 reported estimates of the effects of profit sharing, uncovered in this study, 57\% report positive and statistically significant productivity effects at the $10 \%$ level. Given the growing embrace of profit sharing schemes and the enduring uncertainty in their effects, the time is ripe for a comprehensive evaluation of the relevant research. In this study, we revisit the extant evidence literature through the lenses of meta-regression analysis and make two contributions: an expanded updated meta-analysis review of the evidence base and a new investigation of the role that culture and values might play on profit-sharing effects.

Weitzman and Kruse (1990) and Doucouliagos (1995) present earlier meta-analyses. However, the evidence base has since expanded, and recent studies have shifted the focus on

\footnotetext{
${ }^{1}$ The European estimates are based on data from 34 countries in the 2015 European Working Conditions Survey (http://doi.org/10.5255/UKDA-SN-7363-4). We appreciate the help of Erik Poutsma and Paul Ligthart in calculating these numbers.
} 
the broader international context (Jones and Kato, 1995; Cahuc and Dormont, 1997; Ohkusa and Ohtake, 1997; Kato and Morishima, 2002; 2003; Yao, 1997; Lin et al., 2014). Hence, our meta-analysis is based on a larger number of research studies (56), covering a broader range of countries that include transitional economies: Albania, Bulgaria, Poland, and Ukraine. In their review of 16 studies, Weitzman and Kruse (1990) find that profit sharing has a positive effect on productivity. One limitation with Weitzman and Kruse is that they assign equal weight to all estimates. Doucouliagos (1995) updated Weitzman and Kruse (1990) (19 studies) and used weighted averages that gives greater influence to more precise, more accurate, estimates. By doing so, positive effects were found for both cooperatives and non-cooperatives, though the productivity effect is much larger for cooperatives. Combs et al. (2006) survey 31 studies on incentive compensation and also find a positive effect. However, incentive compensation is not clearly defined and their outcome variable is operational performance, which is a broader concept than productivity. A major limitation with all these prior meta-analyses is that they do not correct estimates for publication selection or model misspecification bias (Stanley, 2001). Our analysis uses a larger sample, is clearly focused on the impact of profit sharing and productivity, and corrects the evidence base for publication selection and misspecification biases.

Our second contribution is to explore the influence of contextual or situational differences (Blasi at al., 2010). This enables us to disentangle some of the channels through which profit sharing impacts productivity. For example, profit sharing increases productivity by increasing incentives to exert more effort. However, free-riding can offset this effect. Consequently, empirical studies report the net effect of profit sharing on productivity. By pooling diverse studies, meta-analysis can make use of variation in contextual factors such as national differences in culture and values that single country studies have not and often cannot investigate. In this paper we focus on three such channels: unions as collective voices, the 
impact of honesty as a proxy for free riding, and the degree of individualism as a measure of national culture. We investigate the impact of variation in these variables across space (countries) and time. Hence, our meta-analysis enables us to explore differences in firm/establishment level context (unionisation) and differences in national level values and culture, where values change over time but culture is time invariant. Often, conventional econometric studies cannot investigate these broader issues of cultural and values, because they are confined to one region and/or time. In this way, meta-regression analysis (MRA) is more than a summary and evaluation of the research record and can explore new dimensions of research beyond the reach of most conventional studies. Our meta-regression analysis enables us to investigate several additional research questions: Does unionisation moderate the effectiveness of profit sharing? Does the impact of profit sharing change when people are believed to behave honestly? Do deep-seated dimensions of culture impact on firm level interventions?

The aims of our meta-analysis are to: (1) provide a statistical synthesis of the existing research on the relationship between group-based profit sharing and productivity; (2) assess the competing claims made about the impact of profit sharing on productivity; (3) examine the effect of moderators such as union density, honesty, free-riding, and national culture; (4) assess the impact of alternative measures of profit sharing and productivity; (5) explore the sensitivity of empirical reported results; and (6) investigate and correct the evidence base for publication and misspecification biases. It is well known that methodological, specification, and data differences impact on empirical estimates (Stanley, 2001). The issue is how to quantify that impact. Meta-analysis is a set of statistical techniques that has been developed to identify and quantify associations drawn from an existing body of literature (Stanley, 2001; Schmidt and Hunter, 2015). Meta-regression analysis is based on a focused examination of the role of 
specification and data sets, among others, on the reported effects of profit sharing on productivity.

We demonstrate that these factors play an important moderating role. Specifically, our results show that unionisation increases the effectiveness of profit sharing, as do more individualistic national cultures. In contrast, perceived honesty reduces the effectiveness of profit sharing, probably as it acts as a substitute for engendering cooperation.

The article is set out as follows. In the next section, we briefly review the theoretical arguments. This is followed by a discussion on the data and the meta-regression methodology in sections 3 and 4, respectively. The results are presented and discussed in section 5, followed by the conclusion in the last section.

\section{Theoretical considerations: Linking profit sharing to productivity}

Group-based bonus plans such as profit sharing can increase productivity by: aligning employee and employer incentives, increasing worker motivation, enhancing work and remuneration flexibility, increasing worker loyalty, and fostering greater teamwork (Kruse, 1993; Blasi et al., 2010). Group-based profit-sharing schemes may be particularly beneficial in situations where it is costly for a manager to measure individual effort, but workers are able to easily observe the performance of their fellow workers, in which case profit sharing may increase cooperation and peer pressure, and reduce monitoring costs. Profit sharing might also serve as a channel to retain good employees. Lower employee turnover amplifies incentives to invest in training, which, in turn, increases human capital and thereby productivity. However, these benefits can be offset by other factors. For example, in group-based incentive schemes, the costs of effort are privately experienced while the benefits from effort are shared collectively. Hence, free riding is a serious possibility, especially in larger groups. Consequently, productivity need not increase if free riding is high. Nevertheless, free-riding 
might be mitigated by peer group pressure and social norms, especially when punishment is co-ordinated (Boyd et al., 2005).

The relation of profit sharing to productivity is further complicated by employee attitudes toward risk and extrinsic motivators. Risk-averse employees may be uncomfortable with any type of variable pay, including profit sharing, and there is some evidence that such employees tend to avoid group incentive plans (Kruse et al., 2010: 65). The risk may be mitigated, however, by having group-based pay come on top of (rather than substitute for) fixed pay, and by supportive policies that give workers greater skills and opportunities to improve performance (Kruse et al., 2010). There is also some social psychology research that suggests extrinsic motivation such as financial incentives may reduce intrinsic motivation, risk-taking, and job satisfaction (Jenkins et al., 1998; Frey and Jegen, 2001), although again these effects may be conditioned by other workplace policies (Kruse et al., 2010: 268-269, 276).

The above considerations suggest that social norms and values may play a significant moderating role. That is, the effectiveness of profit sharing on productivity might be influenced by values such as attitudes towards free riding. Additionally, heterogeneity in profit sharing effectiveness can emerge between industries and from national institutional differences. Our MRA investigates all these sources of heterogeneity with special focus on three contextual variables: unionisation, honesty, and individualism.

\subsection{Unions and profit sharing}

"While there is potential for profit sharing to positively affect performance in a union setting, too little is known to make general conclusions."

Kruse (1993, p. 166).

Unions can affect the incidence and effectiveness of profit sharing. For example, unions and profit sharing might be substitutes. In such cases, we would find a negative association between 
unionisation and the incidence of profit sharing. Where unions provide collective voice mechanisms that increase productivity and reduce turnover of skilled workers, firms may find less need to introduce profit sharing. Alternatively, firms may introduce profit sharing as a strategy to prevent unionisation or to reduce union influence. Profit sharing plans are less common among unionized workers (Kruse, 1996; O’Halloran 2013), which at least partly reflects firms dropping such plans after a union drive (Freeman and Kleiner, 1990). This may reflect the traditional union goal to "take wages out of competition" by standardizing compensation across firms, as well as union concerns about ensuring that profit shares are calculated fairly.

A more interesting possibility is that unions and profit sharing might be complementary to the production process. While profit-sharing schemes are now integrated with some collective bargaining agreements (Del Boca et al., 1999; Blasi, 2016) ${ }^{2}$, unions are often opposed to profit sharing. In the USA, for example, unions have historically been unreceptive to profit-sharing plans (National Civic Federation, 1920; Zalusky, 1990). Nevertheless, unions might serve as a vehicle to make profit sharing more effective for those firms that do introduce profit sharing. For example, if workers are protected by union representation, then they may be more willing to accept schemes such as profit sharing and more committed to make them work. Profit sharing requires financial information and unions can assist profit sharing effectiveness by auditing corporate profits and ensuring fair and appropriate bonuses are paid. Additionally, if profit sharing becomes a significant portion of total compensation, worker interests may become more important in management's decisions that affect profits. Unions can offer a voice for workers in such decisions, helping align the interests of workers and employers. Union

\footnotetext{
${ }^{2}$ For examples see https://www.chron.com/business/article/Southwest-Airlines-to-give-employees586-million-10921211.php; https://uaw.org/uaw-statement-on-gm-profit-sharing/; https://www.freep.com/story/money/cars/chrysler/2017/01/26/fca-union-workers-get-5000-profitsharing-checks/97066284/ (all accessed 5-24-18).
} 
norms of solidarity and reciprocity may also create favourable conditions for peer pressure to help overcome the free rider problem. Profit sharing may then have larger productivity effects in unionised workplaces, which is supported empirically by Cooke (1994) and Fernie and Metcalf (1995), though Lee and Rhee (1996) find that adversarial unions reduce the effectiveness of profit sharing. McCarthy et al. (2011) find greater effects among union workers of group incentives on job satisfaction and performance-related attitudes.

Conversely, confrontational unions may impede profit-sharing effectiveness. For example, in response to profit sharing, unions may question financial information, impede the introduction of new technologies, and resist workplace reforms (Kruse, 1993). Hence, the links between unions and profit-sharing effectiveness are theoretically ambiguous and careful research is needed to distinguish the predominant patterns from these nuances and ambiguities. Bullock and Tubbs (1990) conduct a meta-analysis of gain-sharing plans and find no link between unions and organisational effectiveness. However, their outcome variables combine productivity, costs, and quality.

A related factor is the direct impact of unions on productivity, which is also theoretically ambiguous (Freeman and Medoff, 1984). The extant evidence suggests that unions have an adverse effect on productivity in the UK, a positive effect in some US industries (e.g. construction and mining), and positive productivity effects in developing countries (Doucouliagos et al., 2017). This suggests that the impact of unions on the effectiveness of profit sharing might not be so simple and varying across countries. We collect data on firm (or establishment) level union density and use MRA to investigate whether variation in union density is associated with the reported profit-sharing effects on productivity. 


\subsection{Trust, honesty, and profit sharing}

Team-based work is vulnerable to free-riding (Olson, 1965). However, free-riding can be offset by trust. And, trust and honesty can have a positive effect on a team's performance (Dirks, 1999; De Jong et al., 2016). If high levels of trust reduce free-riding, then trust will be positively correlated with profit-sharing effectiveness. However, high levels of trust may also reduce the need for profit sharing to increase productivity. In circumstances where trust levels are high, teams are likely to already be working with high levels of cooperation, and interventions such as profit sharing may do little to boost productivity further. When trust is high, firms may be less inclined to rely on elaborate safeguards such as profit sharing for monitoring and enforcing workers effort. We would then find a negative correlation between trust and profit-sharing effectiveness, as profit sharing has larger productivity effects in lower trust environments. Kahan (2003, p. 76) argues that: "The simple existence of an incentive scheme can be seen as a cue that other individuals are not inclined to cooperate voluntarily: if they were, incentives would be unnecessary.”

To investigate these dimensions, we use data from the World Values Survey on attitudes to tax evasion (see section 3 for details). People who evade taxes contribute less to the provision of public goods. Hence, we take attitudes towards tax evasion to be broadly representative of values of honesty and of attitudes to free-riding. Attitudes to tax evasion vary between countries and over time and this variation can be used to identify whether attitudes impact profit-sharing effectiveness.

\subsection{Culture and profit sharing}

Corporate culture can affect the effectiveness of profit sharing). The effectiveness of profit sharing may also be influenced by national culture. Hofstede $(1980,2001)$ and Hofstede et al. (2010) argue that national culture traits such as individualism (or its converse, collectivism) 
can deeply affect organisational performance. Empirical evidence reveals the importance of culture (Marcus and Lee, 2013). Gorodnichenko and Roland (2011) show that countries with individualist cultures achieve higher productivity than collectivist cultures. Undoubtedly, corporate culture can differ from national culture. However, corporate culture is influenced by national culture. Indeed, some authors find that national culture can dominate corporate culture (Adler, 1986; Johns, 2006).

We do not have measures of organisational culture for the 56 studies included in the meta-analysis, because it is likely to vary greatly within each study in unmeasured and unmeasurable ways. However, data on national culture differences are available, and they enable our meta-analysis to investigate whether deep-seated attitudes reflected in national culture impact on effectiveness of corporate initiatives such as profit sharing. Specifically, we explore the links between individualism and profit-sharing effectiveness. Hofstede (2001) defines individualism as the "degree to which people in a country prefer to act as individuals rather than as members of groups". Individualistic cultures are orientated towards "I", compared to the collectivist "we". Individualist cultures establish loose ties between people. Data on individualism are time invariant, and reflect that culture is slow to change.

The links between individualism and the effectiveness of profit sharing are theoretically unclear. Gorodnichenko and Roland (2011) argue that collectivism is more conducive to resolving collective action problems and that "collectivism should have an advantage in coordinating production processes and various forms of collective action” (2001, p. 21316). Hence, on this basis, we would expect team-based incentives to be more effective in collectivist cultures and that individual incentives would be more effective in individualistic cultures. Nevertheless, the opposite, though counterintuitive, is also possible for several reasons.

Financial incentives can have a significant impact on employee motivation (Baker et al., 1988). Self-interested individuals may recognise the importance of mutually shared 
interests and the need for collective action, such as the need for team work. If free-riding problems are resolved, self-interest may see greater effort rewarded through profit sharing schemes. Wagner et al. (2012, p. 949) reassess the links between individualism and team performance and conclude that: “ (...) the assumptive basis of the conclusion that member collectivism enhances performance in teams seems questionable (...)” Nations can be individualist orientated but still engage in significant team work. Moreover, as Wagner et al. (2012) note, many team tasks are actually individualized.

The assumption of universal free-riding and non-cooperative behaviour is challenged by many studies (Chaudhuri, 2001; Fehr and Gachter, 2000). The empirical evidence in our meta-analysis is based entirely on observational data from firms engaged in repeated games; groups of workers and managers who need to work together over long periods of times. In such situations, team members can sanction each other to reduce free-riding (Barnes, 1988) or find other ways to resolve such problems and solicit effort. Indeed, profit sharing may offer a solution to some workplace collective action problems. The question then remains whether nations with individualistic or collectivist cultures are better at reducing free-riding in the workplace. In their meta-analysis of the literature on culture and performance, Marcus and Le (2013) find a negative correlation between collectivist societies and performance. Their explanation for this counterintuitive result is that: “(...) people in collectivistic societies are more likely to distinguish between in-groups and out-groups during situations of conflicts or cooperation (...) Because in-groups tend to be narrowly defined in collectivistic societies (e.g., family members, friends, classmates), it is conceivable that work-related group members may not be considered to be in-group members. Consequently, cooperation in work related groups may actually be lower in these societies relative to individualistic societies where little distinction is made between in-groups and out-groups.” (2013, p. 830). 
There is also emerging evidence that individualism can moderate the relationship between profit sharing and productivity. For example, Coyle-Shapiro et al. (2002) demonstrate that profit-sharing plans have a stronger effect on commitment (which often translates into higher productivity) when employees' perceived ability to contribute individually to the firm's profits is high. Similarly, any factor that positively (or negatively) influences such as perceived impact may moderate the relationship between the profit sharing and productivity.

\section{Data}

We followed closely the MAER-Net protocols for conducting and reporting meta-analyses (Stanley et al., 2013). We commenced with a database search for relevant studies in EconLit, ISI Web of Science, Business Source Premier, Ebsco, Scopus, and Google scholar, using combinations of the following broad keywords: "profit sharing", "gain-sharing", "firm performance”, “organization performance”, “team incentives”, “group incentives”, “shared compensation”, “profit-related-pay”, “pay-for-performance”, “productivity”, and "labor productivity”. We also searched manually all the academic journals that have published studies on profit sharing. Our search also included the examination of references in covered empirical studies to other studies that might report profit sharing-productivity effects. Our search was extended to unpublished working papers and theses, the so-called 'grey' literature. The search ended in September 2017. See the appendix for a PRISMA diagram.

It is essential that the data consists of a comparable group of estimates. This necessitates the exclusion of several groups of empirical studies. First, since our focus is on productivity, we exclude estimates of the effects of profit sharing on company performance measured in terms of profitability, wages, or employment. While indirectly related to productivity, these alternate performance outcomes are not comparable to direct productivity effects. Second, we concentrate on firm or establishment level productivity effects; hence we exclude 
macroeconomic studies. Specifically, we focus on studies that estimate a production function and measure output either as value added or sales. Third, we are interested in actual performance outcomes. Hence, we focus on studies using data from actual firms and exclude any experimental (laboratory) based studies. Laboratory based studies may not accurately reflect actual performance of organisations (Roth, 1994; Doucouliagos, 1995). Related to this, we exclude a fourth group of studies that explores managers' perceptions of performance. We focus only on studies that report empirical estimates of objective measures of performance. Fifth, we also exclude studies that include profit sharing as part of a 'bundle' of interventions, e.g. Black and Lynch (2004) and Eriksson (2003). These 'bundled' estimates are not strictly comparable with estimates of the effect of profit sharing on its own.

Sixth, by necessity, we exclude studies that do not report information necessary for calculating effect sizes such as $t$-statistics, correlations, or regression coefficients. Seventh, in a few cases, multiple studies use the same data and report essentially the same results. Here, we include only one of these studies to avoid double-counting (e.g., Yao, 1995). Finally, we include only econometric-based studies and thus exclude studies that report differences between sample means and we also exclude reviews that do not provide any original empirical analysis (e.g. Blanchflower and Oswald, 1987).

Our final data set includes 56 independent studies, covering 18 countries: Albania (1), Bulgaria (1), Canada (2), China (1), Finland (2), France (6), Germany (7), India (1), Italy (5), Japan (3), Korea (1), Netherlands (1), Poland (1), Portugal (1), Taiwan (1), Ukraine (1), UK (8), and the USA (13). The data include two groups of firms: six studies of cooperatives and 50 studies of participatory capitalist firms with profit sharing. The appendix references the studies included in the meta-analysis.

Many studies do not provide sufficient information from which to calculate the percentage change in productivity as a result of profit sharing. Hence, following the approach 
of Doucouliagos and Laroche (2003; 2013) we calculate partial correlations. This is the correlation between profit sharing and productivity controlling for the effects of other factors that potentially influence productivity, such as capital stock. These partial correlations enable us to construct the largest possible dataset of the productivity effects of profit sharing.

We identified five outlying observations by regressing the partial correlation on a constant and its standard error, and treating any observations as an outlier if the absolute value of the standardised residual exceeded 3.5 (for a similar approach see de Linde Leonard et al., 2014). These outliers may represent typing, estimation or coding errors; hence, they are removed from the subsequent meta-regressions to ensure that our findings are not unduly influenced by erroneous information.

These partial correlations measure the 'effect' of profit sharing on productivity. Yet, because productivity might enable the introduction of profit sharing (reverse causation), it is more accurate to interpret these measures as reflecting the strength of the association. Nevertheless, all authors treat the relationship as causal and several studies have attempted to formally accommodate endogeneity. We deal with the potential endogeneity between profit sharing and productivity directly through the meta-regression analysis.

The 56 studies were independently coded by the authors for characteristics of the sample, measurement, and potential moderators (Stanley et al., 2013). The data are illustrated in Figure 1 in the form of a funnel plot (Stanley and Doucouliagos, 2012), showing that: (i) the majority of the estimates report positive profit-sharing effects, (ii) the distribution of results is asymmetrical, and (iii) there is a large degree of heterogeneity in reported findings. An asymmetrical distribution of results may be consistent with publication selection bias but also with heterogeneity among the reported effects (Stanley and Doucouliagos, 2012). In section 5 below, we use MRA to investigate the nuances of potential publication selection and heterogeneity. 


\section{Figure 1: Estimates of profit sharing and productivity correlations}

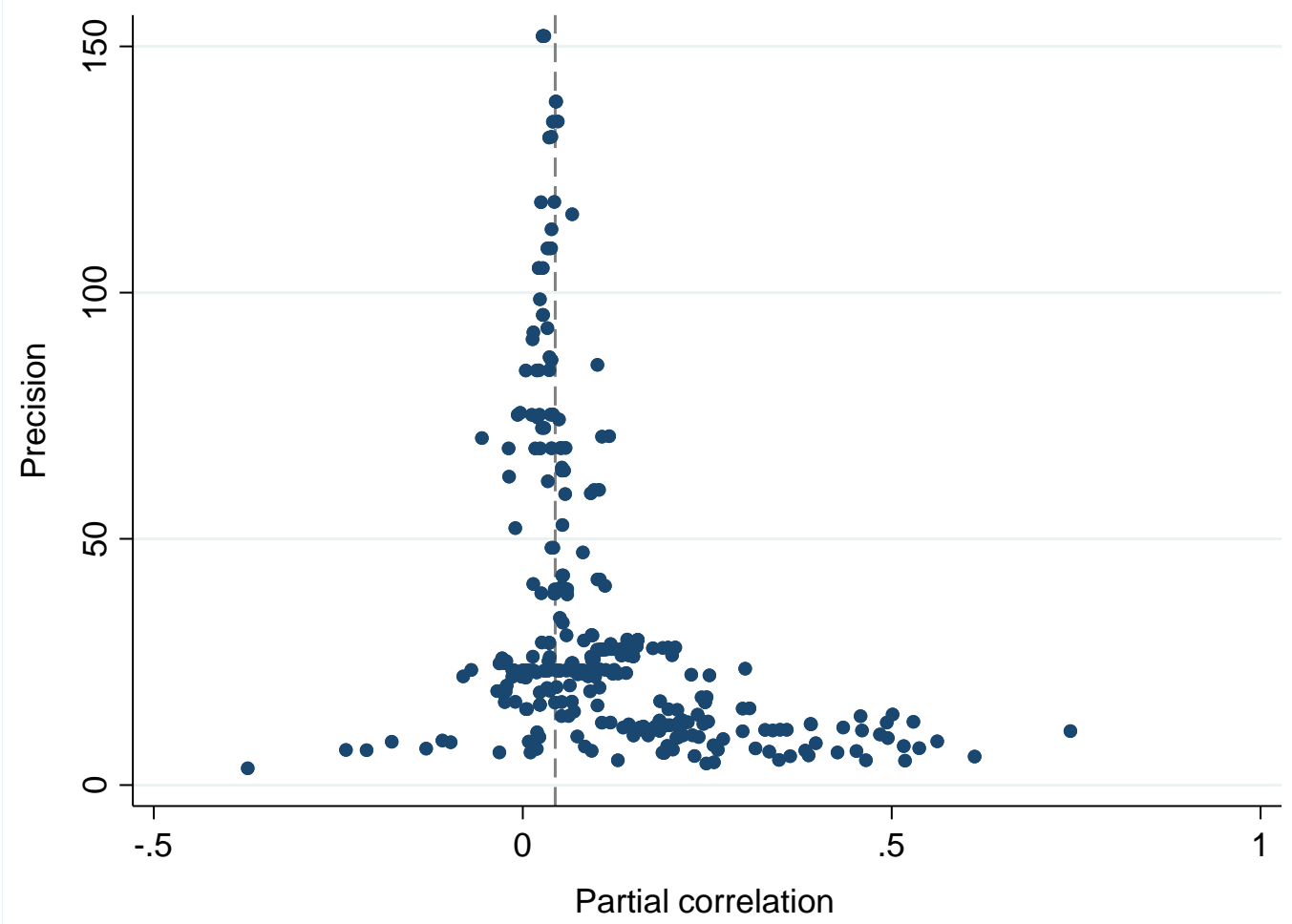

Notes: The dashed vertical line shows the weighted average partial correlation (0.044), using inverse variance weights. Precision is measured as the inverse of the estimated standard error of the partial correlations.

Table 1 presents average partial correlations grouped by ‘cooperatives’ versus ‘noncooperatives' (panel A). Because profit sharing effects from non-cooperative firms represent the vast majority of these estimates, we also breakdown the average partial correlations by various countries for 'non-cooperative,' (panel B). ${ }^{3}$ Profit sharing increases productivity in both cooperative and non-cooperative firms. However, the productivity effects are six times larger for cooperatives and the 95\% confidence intervals do not overlap. The finding that cooperatives have much stronger profit-sharing effects than other firms has been noted before (Doucouliagos, 1995). One explanation for this difference is that workers in cooperatives tend

\footnotetext{
${ }^{3}$ Throughout the paper we use the term 'effect'. However, our measure of effect size is correlations.
} 
to be a self-selected group. They voluntarily choose to work in cooperatives, tend to be coowners, and may thus be more highly motivated. Members of cooperatives are also likely to have greater trust of other members and in the information provided within their firm. Another explanation is that this heterogeneity may reflect differences in profit sharing measures. Nearly all the estimates for cooperatives use a dollar based measure of profits shared, whereas nearly three quarters of the estimates for non-cooperatives use a dummy variable for the presence of profit sharing. Dollar based measures are more likely to reflect endogeneity, as high productivity produces high profit shares. While the sample of estimates is limited, a comparison of endogeneity-corrected dollar-based estimates still suggests a stronger effect of profit sharing in cooperatives than in non-cooperatives. ${ }^{4}$ See the appendix for further comparisons.

Table 1 also reports average productivity effects for non-cooperatives for various countries and groups of countries for the USA, the UK, Germany, Other Europe (Italy, France, Portugal, Netherlands, and Finland), Asia (Japan, China, Taiwan, and Korea), and European transition economies (Albania, Bulgaria, Poland, and Ukraine). ${ }^{5}$ These averages suggest that profit sharing has the largest effect on productivity in Germany and in transition economies. There appears to be a zero correlation for the United Kingdom and for Asian economies. However, these overall averages do not allow heterogeneity and research design differences; we turn to these issues in the following section.

\footnotetext{
${ }^{4}$ The weighted average correlation for dollar based estimates that correct for endogeneity is $0.23(p$-value $=0.252)$ in cooperatives compared to $0.15(p$-value $=0.001)$ in non-cooperatives.

${ }^{5}$ We combine these groups to reduce the burden on degrees of freedom and to construct a simpler model. Analysing these countries separately does not change any of the inferences.
} 
Table 1. Profit sharing and productivity, unconditional weighted averages

\begin{tabular}{|c|c|c|}
\hline Group/Country & $\begin{array}{c}\text { Number of } \\
\text { estimates [studies] } \\
(1) \\
\end{array}$ & $\begin{array}{l}\text { Weighted average } \\
\text { partial correlation } \\
(2) \\
\end{array}$ \\
\hline \multicolumn{3}{|c|}{ A: Cooperatives versus non-cooperatives } \\
\hline Cooperatives & $38[6]$ & $0.253(0.127 ; 0.379)$ \\
\hline Non-cooperatives & $275[50]$ & $0.043(0.032 ; 0.053)$ \\
\hline \multicolumn{3}{|c|}{ B: Country differences (non-cooperatives) } \\
\hline USA & $80[13]$ & $0.036(0.022 ; 0.050)$ \\
\hline United Kingdom & $26[8]$ & $0.033(-0.034 ; 0.099)$ \\
\hline Germany & $26[8]$ & $0.113(0.051 ; 0.175)$ \\
\hline Other Europe: & $85[10]$ & $0.040(0.030 ; 0.051)$ \\
\hline - Italy & $27[3]$ & $0.035(0.023 ; 0.048)$ \\
\hline - France & $22[4]$ & $0.040(0.005 ; 0.075)$ \\
\hline Asia: & $43[8]$ & $0.078(0.007 ; 0.150)$ \\
\hline - Japan & $27[3]$ & $0.077(-0.118 ; 0.273)$ \\
\hline Transition & $15[4]$ & $0.147(0.054 ; 0.240)$ \\
\hline
\end{tabular}

Notes: Column (1) reports the number of observations [and studies] used to calculate the weighted averages. Column (2) reports the weighted average partial correlation estimated with unrestricted weighted least squares using inverse variance weights. Figures in brackets in Column (2) are 95\% confidence intervals. Panel A compares cooperatives to non-cooperatives. Panel B reports country specific averages for non-cooperatives (participatory capitalist firms). See text for definition of Other Europe, Asia, and Transition.

\section{Meta-regression methodology}

Our meta-regression model involves regressing estimates of the partial correlation between profit sharing and productivity, $r$, on a range of moderator and contextual variables:

$$
r_{i j}=\beta_{0}+\beta_{1} S E_{i j}+\beta_{x} \mathbf{x}_{i j}+\beta_{y} \mathbf{y}_{i j}+\varepsilon_{i j}
$$

where $S E$ is the estimated standard error of the partial correlation, $\mathbf{x}$ is a vector of moderator variables that reflect research design choices (e.g., econometric specification, years, countries, and industries studied), $\mathbf{y}$ is a vector of contextual variables (e.g., union density, values, and culture), $\mathrm{i}$ and $\mathrm{j}$ index denote estimates and studies, respectively, and $\varepsilon$ denotes the error term.

We estimate Eqn. (1) using data from the 50 studies that report 275 estimates of profit sharing for participatory capitalist firms. We exclude cooperatives from this analysis in order to ensure a focussed analysis on participatory capitalist firms. The dataset contains several estimates from the same study, so that estimates are clustered within studies. We deal with this potential data dependence by adjusting standard errors for data clustering within studies. 
Estimation of Eqn. (1) achieves three tasks. First, Eqn. (1) can be used to correct the evidence base for publication selection bias and econometric misspecification bias (see Stanley and Doucouliagos, 2012). If the empirical literature is free of publication selection bias, then the estimated profit-sharing partial correlations will not be correlated with their standard errors (Egger et al., 1997; Stanley 2005, 2008). ${ }^{6}$ In contrast, some researchers might search for estimates that are statistically significant at an 'acceptable' significance level. Such selection will often generate a correlation between an estimated effect and its standard error and can result in a truncated and asymmetrical distribution of reported profit-sharing effects (Stanley 2008; Stanley and Doucouliagos, 2014). Hence, publication selection bias can be statistically investigated by testing the coefficient on the standard error (SE), $\beta_{1}=0$, also known as the funnel asymmetry test (or FAT).

Second, Eqn. (1) can also be used to identify the factors that generate heterogeneity in reported estimates. Parts of this heterogeneity will reflect genuine differences in profit sharing effects, but some heterogeneity will also be created by research design choices. Heterogeneity can be identified and quantified by the coefficients in the $\mathbf{x}$ and $\mathbf{y}$ vectors in Eqn. (1). The $\mathbf{x}$ vector contains information extracted from the primary studies themselves, such as the samples used (e.g., country, time period, and panel data). This enables us to explore heterogeneity both in terms of data and in terms of research design choices. By identifying the impact of specification on reported estimates, through the variables included in the $\mathbf{x}$ vector, it is possible to 'correct' the evidence base for misspecification bias. The $\mathbf{y}$ vector contains information collected from external sources and is used to quantify the impact of contextual factors; see below discussion.

\footnotetext{
${ }^{6}$ Calculation of the standard deviation of the partial correlation requires an estimate of the partial correlation. Hence, there is some correlation between these two variables. To get around this, authors sometimes use the Fisher z-transformation (e.g., Doucouliagos and Laroche, 2003). However, this transformation makes little difference. Results using the $z$-transformation are reported in the appendix.
} 
Third, the estimated coefficients from Eqn. (1) can be used to quantify the size of the profit-sharing effect; the coefficients from the meta-regressions provide estimates of the effect of profit sharing on productivity, corrected for publication selection, model misspecification bias, heterogeneity, and adjusted for context.

The moderator variables used to explore genuine heterogeneity and heterogeneity introduced by research design choices are listed in Table 2 .

$S E$ is the estimated standard error of the partial correlation and is included to accommodate the potential presence of publication selection. Unpublished is a binary variable for unpublished studies. Seven binary variables are included relating to the country or region studied by primary studies: UK, Canada, Germany, Other Europe (all other European nations), Japan, Asia (excluding Japan), and Transition (transition economies). The baseline (omitted category) is the USA.

We include seven variables that reflect data differences. Year is the average year of the data used by studies. Continuous is a binary variable for studies that measure profit sharing as a continuous measure with studies that use a dummy variable (the incidence of profit sharing) as the base. Panel, Nonmanuf, and Managerial are binary variables for panel data, data relating to non-manufacturing industries, and profit sharing for managerial staff, respectively; with profit sharing for cross-sectional data for manufacturing non-managerial employees as the baseline. Number of firms is the number of firms or establishments used by primary studies.

Ten binary variables reflect specification and estimation differences. Decision and Ownership reflect studies that control for employee participation in decision making and ownership, respectively. These are important dimensions of participatory firms that may also affect productivity. The moderator variables Human capital, Market share, Capital, and Age, are included to reflect studies that control for human capital or skill differentials, market share or firm concentration, capital stock, and age of firm/establishment, respectively. Endogeneity 
controls for studies that have attempted, in some fashion, to address the issue of reverse causality between profit sharing and productivity. Finally, Random effects, Fixed effects, and Time effects control for studies that use a random effects panel model, and studies that control for firm specific and time specific fixed effects, respectively.

The $\mathbf{y}$ vector contains the three contextual variables: union density, tax evasion, and individualism. Most of this information on these variables was collected from sources external to the primary studies. While some primary studies included union density, none considered the other contextual variables.

Union density is the average percent of workforce that is unionized. This variable is included to investigate whether the impact of profit sharing on productivity is conditional upon the degree of unionisation. This serves as a proxy for the power of unions. As discussed in section 2 above, unions may facilitate or hinder the effectiveness of profit sharing. In most cases, data on union density are reported in the studies themselves and relate to unionisation at the firm or establishment level. However, in a handful of cases, we use national level data on unionisation (matched to the country and time period studied by the primary studies) to proxy for the sample specific unionisation; this decision does not influence results.

Tax evasion is the proportion of respondents who state that tax evasion is never justified. This variable was constructed using data from various issues of the World Values Survey (WVS). For countries not included in the WVS, we use the equivalent responses from the European Values Study. We use the response to the following question: "Please tell me for each of the following statements whether you think it can always be justified, never be justified, or something in between, using this card. Cheating on taxes if you have a chance”. We use the percent of responses stating that cheating on taxes is never justified. ${ }^{7}$ Recall from section 2 that

\footnotetext{
${ }^{7}$ The actual question number in the surveys has changed over time but the question has not. Data was extracted from the ASEP/JDS website: http://www.jdsurvey.net/jds/jdsurveyAnalisis.jsp?ES_COL=131\&Idioma=I\&SeccionCol=06\&ESID=397. Accessed 31 May 2018.
} 
a major issue in the effectiveness of profit sharing is the degree of free-riding. We use this variable to reflect the degree to which people are trustworthy and unlikely to free ride. The data relate to national differences in attitudes to tax evasion. These change over time; so there is variation in this trust indicator across both space and time. One limitation with these data is that they are based on self-reported measures of trust and hence may be biased if survey responders misrepresent their true attitudes to tax evasion.

The third contextual variable is Individualism. The data for this dimension of culture are based on the work of Hofstede (1980). These data are at the national level and are time invariant. We hypothesize that the effectiveness of collective incentive remuneration may be influenced by the degree of individualism.

The moderator variables can be reasonably taken to be exogenous to the estimated profit-sharing effects. For example, national attitudes to tax evasion and individualism are unlikely to be influenced by the effectiveness of profit sharing, especially considering the low incidence of profit sharing in most countries. Hence, our MRA estimates are unlikely to suffer from reverse causality bias. However, reverse causality with union density is more plausible. 
Table 2. MRA Moderator Variables

\begin{tabular}{|c|c|c|c|c|}
\hline Variable & Description & Source of data & Mean & $\begin{array}{l}\text { Standard } \\
\text { deviation }\end{array}$ \\
\hline$r$ & $\begin{array}{l}\text { Partial correlation, the dependent } \\
\text { variable }\end{array}$ & Primary studies & 0.091 & 0.116 \\
\hline$S E$ & $\begin{array}{l}\text { Standard error of the partial } \\
\text { correlation }\end{array}$ & Primary studies & 0.049 & 0.037 \\
\hline Unpublished & Unpublished study & Primary studies & 0.138 & 0.345 \\
\hline$U K$ & UK sample & Primary studies & 0.095 & 0.293 \\
\hline Canada & Canadian sample & Primary studies & 0.011 & 0.104 \\
\hline Germany & German sample & Primary studies & 0.095 & 0.293 \\
\hline Other Europe & Other European country sample & Primary studies & 0.309 & 0.463 \\
\hline Japan & Japanese sample & Primary studies & 0.098 & 0.298 \\
\hline Asia & $\begin{array}{l}\text { Asian sample data (excluding } \\
\text { Japan) }\end{array}$ & Primary studies & 0.047 & 0.213 \\
\hline Transitional & Transitional economy sample & Primary studies & 0.055 & 0.228 \\
\hline \multicolumn{5}{|c|}{ Data } \\
\hline Average Year & $\begin{array}{l}\text { Average year of sample normalized } \\
\text { to sample mean year, } 1986\end{array}$ & Primary studies & 0.961 & 7.640 \\
\hline Nonmanuf & $\begin{array}{l}\text { Non-manufacturing sample data } \\
\text { (base is manufacturing) }\end{array}$ & Primary studies & 0.494 & 0.501 \\
\hline Panel & Panel data (base is cross-sectional) & Primary studies & 0.756 & 0.430 \\
\hline Continuous & $\begin{array}{l}\text { Non-binary measure of profits } \\
\text { sharing used (base is binary } \\
\text { measure) }\end{array}$ & Primary studies & 0.273 & 0.446 \\
\hline Salesbased & $\begin{array}{l}\text { Sales based productivity measure } \\
\text { (base is value added measure) }\end{array}$ & Primary studies & 0.230 & 0.422 \\
\hline Number of firms & $\begin{array}{l}\text { The number of firms in the } \\
\text { data/1000 }\end{array}$ & Primary studies & 0.695 & 1.480 \\
\hline Managerial & $\begin{array}{l}\text { Profit sharing for managerial staff } \\
\text { (base is non-managerial staff) }\end{array}$ & Primary studies & 0.029 & 0.168 \\
\hline \multicolumn{5}{|c|}{ Econometric specification and estimation } \\
\hline Decision & $\begin{array}{l}\text { Model controls for employee } \\
\text { participation in decision making }\end{array}$ & Primary studies & 0.135 & 0.342 \\
\hline Ownership & $\begin{array}{l}\text { Model controls for employee } \\
\text { ownership }\end{array}$ & Primary studies & 0.316 & 0.466 \\
\hline Human capital & Model controls for human capital & Primary studies & 0.193 & 0.395 \\
\hline Market share & $\begin{array}{l}\text { Model controls for market share or } \\
\text { industry concentration }\end{array}$ & Primary studies & 0.171 & 0.377 \\
\hline Capital & Model controls for physical capital & Primary studies & 0.745 & 0.436 \\
\hline Age & Model controls for age of firm & Primary studies & 0.164 & 0.371 \\
\hline Endogeneity & Estimation corrects for endogeneity & Primary studies & 0.113 & 0.317 \\
\hline Fixed effects & $\begin{array}{l}\text { Estimation with firm or industry } \\
\text { fixed effects }\end{array}$ & Primary studies & 0.502 & 0.501 \\
\hline Time effects & Estimation with time fixed effects & Primary studies & 0.655 & 0.476 \\
\hline Random effects & Estimation with random effects & Primary studies & 0.113 & 0.317 \\
\hline \multicolumn{5}{|c|}{ Contextual variables (y vector) } \\
\hline Tax evasion & $\begin{array}{l}\% \text { of survey responders stating it is } \\
\text { never justified to cheat on taxes }\end{array}$ & $\begin{array}{l}\text { World Values } \\
\text { Survey \& } \\
\text { European Values } \\
\text { Study }\end{array}$ & 58.319 & 12.396 \\
\hline Individualism & $\begin{array}{l}\text { The extent people in a society are } \\
\text { integrated into groups }\end{array}$ & Geert Hofstede & 69.375 & 23.497 \\
\hline Union density & Union density & $\begin{array}{l}\text { Primary studies } \\
\text { and OECD }\end{array}$ & 0.310 & 0.160 \\
\hline
\end{tabular}




\section{Results}

The key MRA results are presented in Table 3, and the full set of results are reported in the appendix. Column (1) reports the general MRA model with estimates of the effects of all moderator variables included, except for the contextual variables. In Column (2) we add the three contextual variables - Union density, Tax evasion, and Individualism - serving as proxies for the power of insiders, the degree of honesty, and the culture of individualism, respectively. Column (3) reports the results of a general-to-specific modelling strategy that removes any moderator variable that was not statistically significant at the $10 \%$ level. This is a recommended approach to simplifying complex MRA models to avoid the real possibility that multicollinearity might obscure the central message(s) (Stanley and Doucouliagos, 2012). All these models are estimated using unrestricted weighted least squares meta-regression using inverse variance $\left(1 / s e^{2}\right)$ weights, as recommended by Hedges and Olkin (1985) and extended by Stanley and Doucouliagos (2015; 2017).

Columns (4) and (5) explore the robustness of the MRA estimates to different weights. Column (4) replaces inverse variance weights with sample size, as recommended by Schmidt and Hunter (2015). Column (5) uses random effects weights, $1 /\left(\mathrm{se}^{2}+\tau^{2}\right)$, where $\tau^{2}$ is the estimate of random effects variance (the between-study or heterogeneity variance). These models, however, have been shown to result in biased estimates when a literature faces publication selection bias (Stanley and Doucouliagos, 2015; 2017). 
Table 3: Profit sharing and Productivity, Meta-Regression Analysis

\begin{tabular}{|c|c|c|c|c|c|}
\hline & $\begin{array}{c}(1) \\
\text { General }\end{array}$ & $\begin{array}{c}(2) \\
\text { General } \\
\text { with } \\
\text { values and } \\
\text { culture } \\
\end{array}$ & $\begin{array}{c}(3) \\
\text { Specific } \\
\text { with } \\
\text { values and } \\
\text { culture }\end{array}$ & $\begin{array}{c}(4) \\
\text { Sample } \\
\text { size } \\
\text { weights }\end{array}$ & $\begin{array}{c}\text { (5) } \\
\text { Random } \\
\text { effects }\end{array}$ \\
\hline \multicolumn{6}{|c|}{ A: Meta-regressions } \\
\hline Constant & $\begin{array}{l}-0.003 \\
(-0.10)\end{array}$ & $\begin{array}{l}0.007 \\
(0.07)\end{array}$ & $\begin{array}{c}-0.082 \\
(-2.83) * * *\end{array}$ & $\begin{array}{c}-0.071 \\
(-2.41)^{* *}\end{array}$ & $\begin{array}{c}-0.080 \\
(-2.20)^{* *}\end{array}$ \\
\hline$S E$ & $\begin{array}{c}1.395 \\
(4.35)^{* * *}\end{array}$ & $\begin{array}{c}1.590 \\
(3.97)^{* * *}\end{array}$ & $\begin{array}{c}1.945 \\
(6.47)^{* * *}\end{array}$ & $\begin{array}{c}1.761 \\
(5.85)^{* * *}\end{array}$ & $\begin{array}{c}1.891 \\
(8.43)^{* * *}\end{array}$ \\
\hline Endogeneity & $\begin{array}{c}0.041 \\
(3.24)^{* * *}\end{array}$ & $\begin{array}{c}0.047 \\
(3.79)^{* * *}\end{array}$ & $\begin{array}{c}0.051 \\
(4.38)^{* * *}\end{array}$ & $\begin{array}{c}0.049 \\
(4.17)^{* * *}\end{array}$ & $\begin{array}{c}0.042 \\
(2.98)^{* * *}\end{array}$ \\
\hline Average year & $\begin{array}{l}-0.001 \\
(-0.89)\end{array}$ & $\begin{array}{l}-0.001 \\
(-0.73)\end{array}$ & - & - & - \\
\hline Number of firms & $\begin{array}{c}0.005 \\
(3.46)^{* * *}\end{array}$ & $\begin{array}{c}0.006 \\
(4.20)^{* * *}\end{array}$ & $\begin{array}{c}0.005 \\
(3.61)^{* * *}\end{array}$ & $\begin{array}{c}0.005 \\
(3.49)^{* * *}\end{array}$ & $\begin{array}{l}0.004 \\
(1.51)\end{array}$ \\
\hline Capital & $\begin{array}{l}-0.004 \\
(-0.30)\end{array}$ & $\begin{array}{l}0.009 \\
(0.51)\end{array}$ & $\begin{array}{c}0.028 \\
(3.03)^{* * *}\end{array}$ & $\begin{array}{c}0.029 \\
(3.08)^{* * *}\end{array}$ & $\begin{array}{c}0.022 \\
(1.74)^{*}\end{array}$ \\
\hline Time dummies & $\begin{array}{l}0.010 \\
(0.83)\end{array}$ & $\begin{array}{c}0.019 \\
(1.95)^{*}\end{array}$ & $\begin{array}{c}0.020 \\
(2.49)^{* *}\end{array}$ & $\begin{array}{c}0.017 \\
(2.24)^{* *}\end{array}$ & $\begin{array}{c}0.032 \\
(3.09)^{* * *}\end{array}$ \\
\hline Age & $\begin{array}{l}0.029 \\
(1.14)\end{array}$ & $\begin{array}{l}0.024 \\
(1.08)\end{array}$ & $\begin{array}{c}0.024 \\
(2.15)^{* *}\end{array}$ & $\begin{array}{c}0.024 \\
(2.12)^{* *}\end{array}$ & $\begin{array}{l}0.013 \\
(0.99)\end{array}$ \\
\hline Human capital & $\begin{array}{l}0.002 \\
(0.10)\end{array}$ & $\begin{array}{l}-0.022 \\
(-1.05)\end{array}$ & $\begin{array}{c}-0.016 \\
(-2.13)^{* *}\end{array}$ & $\begin{array}{c}-0.019 \\
(-2.30)^{* *}\end{array}$ & $\begin{array}{l}-0.002 \\
(-0.22)\end{array}$ \\
\hline Union density & - & $\begin{array}{c}0.099 \\
(2.31)^{* *}\end{array}$ & $\begin{array}{c}0.070 \\
(4.40)^{* * *}\end{array}$ & $\begin{array}{c}0.066 \\
(4.18)^{* * *}\end{array}$ & $\begin{array}{l}0.038 \\
(1.36)\end{array}$ \\
\hline Tax evasion & - & $\begin{array}{l}-0.002 \\
(-1.39)\end{array}$ & $\begin{array}{c}-0.002 \\
(-2.94) * * *\end{array}$ & $\begin{array}{c}-0.002 \\
(-2.85)^{* * *}\end{array}$ & $\begin{array}{c}-0.001 \\
(-2.07)^{* *}\end{array}$ \\
\hline Individualism & - & $\begin{array}{c}0.001 \\
(2.06)^{* *}\end{array}$ & $\begin{array}{c}0.001 \\
(4.87)^{* * *}\end{array}$ & $\begin{array}{c}0.001 \\
(4.46)^{* * *}\end{array}$ & $\begin{array}{c}0.001 \\
(3.18)^{* * *}\end{array}$ \\
\hline USA & $\begin{array}{c}\text { B: Country s } \\
0.08 \\
(-0.01 ; 0.17)\end{array}$ & $\begin{array}{c}\text { pecific weigh } \\
0.07 \\
(0 ; 16)\end{array}$ & $\begin{array}{c}\text { ted averages } \\
0.06 \\
(0.03 ; 0.10)\end{array}$ & $\begin{array}{c}0.06 \\
(0.02 ; 0.10)\end{array}$ & $\begin{array}{c}0.06 \\
(0.02 ; 0.11)\end{array}$ \\
\hline UK & $\begin{array}{c}0.06 \\
(-0.03 ; 0.15)\end{array}$ & $\begin{array}{c}0.04 \\
(-0.05 ; 0.12)\end{array}$ & $\begin{array}{c}0.02 \\
(-0.04 ; 0.08)\end{array}$ & $\begin{array}{c}0.02 \\
(-0.04 ; 0.08)\end{array}$ & $\begin{array}{c}0.02 \\
(-0.03 ; 0.07)\end{array}$ \\
\hline Germany & $\begin{array}{c}0.10 \\
(0 ; 0.20)\end{array}$ & $\begin{array}{c}0.08 \\
(-0.01 ; 0.17)\end{array}$ & $\begin{array}{c}0.07 \\
(0.04 ; 0.10)\end{array}$ & $\begin{array}{c}0.07 \\
(0.04 ; 0.10)\end{array}$ & $\begin{array}{c}0.07 \\
(0.03 ; 0.11)\end{array}$ \\
\hline Japan & $\begin{array}{c}0.08 \\
(-0.02 ; 0.18)\end{array}$ & $\begin{array}{c}0.07 \\
(-0.01 ; 0.16)\end{array}$ & $\begin{array}{c}0.08 \\
(0.04 ; 0.12)\end{array}$ & $\begin{array}{c}0.08 \\
(0.03 ; 0.13)\end{array}$ & $\begin{array}{c}0.09 \\
(0.05 ; 0.13)\end{array}$ \\
\hline Transition & $\begin{array}{c}0.14 \\
(0.04 ; 0.24)\end{array}$ & $\begin{array}{c}0.20 \\
(0.08 ; 0.32)\end{array}$ & $\begin{array}{c}0.19 \\
(0.13 ; 0.25)\end{array}$ & $\begin{array}{c}0.20 \\
(0.14 ; 0.25)\end{array}$ & $\begin{array}{c}0.17 \\
(0.10 ; 0.24)\end{array}$ \\
\hline $\mathrm{N}[\mathrm{k}]$ & $275[50]$ & $267[48]$ & 267 [48] & $267[48]$ & $267[48]$ \\
\hline Adjusted $\mathrm{R}^{2}$ & 0.34 & 0.36 & 0.37 & 0.36 & - \\
\hline
\end{tabular}

Notes: Only the key variables reported; see the appendix for full results and Table 2 for variable definitions and summary statistics. Column (1) reports the general model including the full set of controls but excluding contextual variables. Column (2) adds three contextual variables: Union density, Tax evasion, and Individualism. Column (3) reports the general-to-specific MRA after removing all statistically insignificant variables. Columns (1) to (3) use weighted least squares with inverse variance weights ( $\left.w=1 / S E^{2}\right)$. Column (4) uses sample size weights, while Column (5) uses random effect weights $\left(w=1 /\left(S E^{2}+\tau^{2}\right)\right.$, where $\tau^{2}$ is the estimate of the between-study or heterogeneity variance. Brackets report $t$-statistics using standard errors adjusted for study-level clustering. *, **, and ${ }^{* * *}$ denote statistical significance at the $10 \%, 5 \%$, and $1 \%$ levels, respectively. Panel B reports weighted averages for various countries evaluated using country specific sample averages for contextual variables. 
Several of the variables appear to be important moderators of the effect of profit sharing on productivity. SE always has a positive and statistically significant coefficient, consistent with some researchers selectively reporting statistically significant positive profit-sharing effects. The degree of bias may be considered substantial because its coefficient is consistently larger than 1 (Stanley and Doucouliagos, 2013). ${ }^{8}$

Reverse causality is a major concern in this area of research. For example, profit sharing may be introduced by the more productive firms. The coefficient on Endogeneity indicates that studies that do not treat reverse causality find smaller effects. In particular, simple OLS models produce smaller estimates. Correcting for reverse causality results in partial correlations that are about 0.05 larger, giving further credence that the positive profit-sharing effect is authentic.

The number of firms included in the sample is important; larger productivity effects emerge as samples are broadened to embrace more firms. This finding is consistent with an underlying positive productivity effect that is more likely to be revealed by the greater statistical power of larger samples. ${ }^{9}$

Measurement appears to be unimportant. Specifically, conditional on the other dimensions of research design and data, it makes little difference to the size of the productivity effect if profit sharing is measured as a continuous measure or as a binary variable for the presence of profit sharing. However, the specification of the econometric model moderates the size of the profit-sharing productivity effect. Specifically, studies report smaller productivity effects if they do not control for the contributions of capital, the age of the firm or establishment, and time dummies to control for unobservable time effects, i.e., excluding these variables results in model misspecification bias in the direction of reporting smaller effects.

\footnotetext{
${ }^{8}$ We are not suggesting that all authors take part in this process. Rather, it appears that some results produced in some studies are likely to be missing from the reported evidence base. Applying the coefficients on SE in Table 3 to the average $S E$ (0.049) implies that most (and perhaps all) of the average positive correlation between profit sharing and productivity (0.091) can be attributed to selective reporting or small sample bias.

${ }^{9}$ Larger samples will tend to report estimates with greater precision. However, this does not necessarily mean that larger samples will produce larger effects.
} 
Conversely, studies that exclude human capital report larger productivity effects, suggesting that some of the productivity effect attributed to profit sharing stems from human capital rather than profit sharing directly. As discussed in Section 2, above, profit sharing may enable retention of more productive employees and thereby causing profit sharing to impact productivity through human capital investment.

The three contextual variables also play important moderating roles, explaining some of the heterogeneity among reported estimates. The positive coefficient on Union density suggests that unions and profit sharing are complementary; that is unions enhance the profit sharing effect on productivity. These findings are consistent with the importance of collective voice mechanisms. Greater voice, representation, and protection of workers can induce profit sharing to be more effective in increasing productivity.

Tax evasion has a negative coefficient. Recall that this variable reflects general societal views that "Tax evasion is never justifiable” and serves as a proxy for attitudes towards free riding in a society. The negative coefficient suggests that profit sharing has weaker productivity effects in societies with higher (self-reported) levels of trust and honesty. This result is consistent with the idea that a high level of trust already engenders a larger degree of cooperation. Consequently, profit sharing may not contribute as much to promote productivity i.e., productivity is already likely to be higher because of higher trust and profit sharing does not add as much to productivity.

Individualism has a positive coefficient suggesting that profit sharing has a greater effect on productivity in more individualistic cultures. At first blush, this finding seems counterintuitive given that we are assessing the effectiveness of group-based profit-sharing schemes. Evidently, individualistic national cultures are not a hindrance to group-based incentive schemes. As discussed in Section 2, if free-riding problems can be resolved, selfinterested, individualistic workers may see how greater efforts are rewarded through profit 
sharing schemes. Moreover, this finding may have a similar explanation as for the tax evasion result; collectivist cultures already cooperate, so a cooperation-enhancing policy like profit sharing may only be needed, or will be more effective, in an individualistic culture where it gets people to see past their narrow self-interest.

\section{Country differences}

The MRA results reported in Table 3 account for a large proportion of the variation in reported estimates. In addition to explaining the heterogeneity in the results, the MRA coefficients can also be used to evaluate the size of the profit-sharing effect for particular countries or conditional on 'best practice'. We present conditional meta-averages using the coefficients from the MRA in panel B of Table 3 for several countries evaluated using: individual country sample means of the contextual variables (union density, individualism, and attitudes to tax evasion), the country sample mean of the number of firms studies, and assuming that best practice econometric modelling for this literature controls for reverse causality, physical and human capital, firm age, and fixed time effects.

These meta-regressions suggest that the correlation between profit sharing and productivity is about 0.07 in the USA, Germany, and Japan. However, it is effectively zero in the UK. The effect is strongest in transition economies. These results differ from the unconditional estimates reported in Table 1, as they correct for potential publication selection bias and model misspecification.

Our findings for transition economies might be driven by sparse data. Alternatively, profit sharing in transitional economies may have been introduced, initially, into firms that were receptive to it. Further study is needed to confirm if this is a lasting finding. 


\section{Discussion and Conclusion}

Profit sharing is often promoted as a means of boosting firm productivity by increasing workplace cooperation, information-sharing, and employee commitment. Evidence has been mixed, with many studies finding no effect on productivity, others a positive effect and some studies reporting adverse productivity effects. We find that the majority (57\%) of the 313 coefficients in our 56 studies are positive and statistically significant at the $10 \%$ level. The average partial correlation between profit sharing and productivity is 0.253 for cooperatives and 0.043 for non-cooperatives, both significantly greater than zero. The latter result is remarkably close to the small but significant 0.04 partial correlation between employee ownership and performance found in the meta-analysis by O’Boyle et al. (forthcoming). Profit sharing and employee ownership obviously share the feature of tying worker compensation to company performance, although there are clear differences, in particular that profit sharing provides a more immediate reward while employee ownership creates greater issues of financial diversification.

This positive relationship between profit sharing and productivity holds up in our metaregression analysis. It is noteworthy that the effect is strengthened when accounting for reverse causality, and is stronger in studies that (properly) control for capital intensity. The effect is somewhat reduced when controlling for human capital levels, indicating that part of the positive effect of profit sharing may come from the effects of higher human capital (possibly due to workers with higher human capital being attracted to profit sharing schemes).

Simply installing a profit sharing plan, however, does not lead to automatic improvement. There is substantial dispersion in the effects of profit sharing. We find that profit sharing appears to be more effective in the presence of unions, consistent with the idea that unions provide job security, voice, and opportunities for worker cooperation that enhance the effect of profit sharing. We also find that profit sharing has a larger effect on productivity in 
countries where honesty is less highly valued, and in countries with higher levels of individualism. Both of these results at first appear counterintuitive, since workplace cooperation should work better in companies where workers trust each other and are more prone to cooperate. These results may indicate, however, that profit sharing works best at inspiring workplace cooperation in settings where cooperation does not naturally occur; that is, cooperation may enhance productivity, and profit sharing may be especially useful to encourage such cooperation in cultures with low social trust and high levels of individualism. These results clearly warrant further research.

The results have implications for firms, policy makers, and researchers. For firms, the results indicate that contextual factors are very important. The improvement in outcomes is better, on average, among firms that adopt profit sharing but has a wide dispersion (recall Figure 1), indicating that some adopters do extremely well while others see decreases in performance (Kruse, 1993). Recent evidence suggests that profit sharing, employee ownership, and other group incentives work better when combined with high-performance policies of employee involvement, training, job security, market-level fixed wages, and low supervision (Kruse et al., 2010, Blasi et al., 2016).

For policy makers, the results suggest that profit sharing may help, and at a minimum will not harm, economic performance. The United States has a long history of encouraging broader sharing of economic rewards, starting with George Washington’s policy to rebuild the cod fishing fleet (which had been decimated by the British in the Revolutionary War) with tax credits for ships that established profit sharing plans for sailors (Blasi et al., 2014). Washington and other founders believed that greater sharing of economic rewards would strengthen democracy by mitigating economic inequality, which is highly relevant given current trends toward inequality. To the extent that profit sharing provides a social good, these results indicate at a minimum that it will not come with an economic cost. A variety of public policy ideas to 
encourage greater sharing of economic rewards with employees is discussed in Blasi et al. (2014).

For researchers, the results suggest that while profit sharing improves performance on average, there is still much to learn about how this happens, and a substantial amount of dispersion to be explained. While a common criticism is that the positive effects reflect reverse causality, these meta-regression results indicate the relationship is actually strengthened when accounting for this endogeneity. Some of the deeper explanation should involve more direct measurement of worker behaviours and motivations. For example, Freeman et al. (2010) found that workers with profit sharing, employee ownership, or other group incentive schemes were more likely to take action against a shirking co-worker, and a large portion of those workers said it was because "poor performance will cost me or other workers in bonus or stock value" (Freeman et al., 2010: 97). It would be immensely useful to have more such measures of worker attitudes and behaviour, including the types of cultural attitudes measured here, to better unlock the question of how and why profit sharing affects productivity.

\section{References}

Adler NJ (1986) International Dimensions of Organizational Behavior. Mason: Thomson South Western.

Baker GP, Jensen MC and Murphy KJ (1988) Compensation and incentives: Practice vs. theory. Journal of Finance 43(3): 593-616.

Barnes B (1988) The Nature of Power. Urbana: University of Illinois Press.

Black SE and Lynch LM (2004) What's driving the new economy?: The benefits of workplace innovations. The Economic Journal 114(493): F97-F116.

Blanchflower D and Oswald AJ (1987) Profit sharing-can it work? Oxford Economic Papers 39(1): 1-19.

Blasi JR (2016) Profit sharing: Labor's new opportunity. https://www.huffingtonpost.com/joseph-blasi/profit-sharing-labors-new_b_8096882.html

Blasi JR, Freeman RB and Kruse DL (2014) The Citizen's Share: Putting Ownership Back into Democracy. New Haven, CN: Yale University Press.

Blasi JR, Freeman RB and Kruse DL (2016) Do broad-based employee ownership, profit sharing and stock options help the best firms do even better? British Journal of Industrial Relations 54(1): 55-82.

Blasi JR, Kruse DL and Markowitz HM (2010) Risk and lack of diversification under employee ownership and shared capitalism. In Kruse DL, Freeman RB and Blasi JR (eds.), Shared 
Capitalism at Work: Employee Ownership, Profit and Gain Sharing, and Broad-Based Stock Options. Chicago, IL: University of Chicago Press, pp. 105-136.

Blinder AS (ed.) (2011) Paying for Productivity: A Look at the Evidence. Washington, D.C.: Brookings Institution Press.

Boyd R, Gintis H and Bowles S (2005) Coordinated punishment of defectors sustains cooperation and can proliferate when rare. Science 328, 30 April: 617-20.

Bullock J and Tubbs ME (1990) A case meta-analysis of gainsharing plans as organizational development interventions. The Journal of Applied Behavioral Science 26(3): 383-404.

Cahuc P and Dormont B (1997) Profit-sharing: Does it increase productivity and employment? A theoretical model and empirical evidence on French micro data. Labour Economics 4(3): 293-319.

Chaudhuri A (2011) Sustaining cooperation in laboratory public goods experiments: A selective survey of the literature. Experimental Economics 14(1): 47-83.

Combs J, Liu Y, Hall A and Ketchen D (2006) How much do high-performance work practices matter? A meta-analysis of their effects on organizational performance. Personnel Psychology 59(3): 501-28.

Coyle-Shapiro JAM, Morrow PC, Richardson R and Dunn SR (2002) Using profit sharing to enhance employee attitudes: A longitudinal examination of the effects on trust and commitment. Human Resource Management 41(4): 423-39.

De Jong BA, Dirks KT and Gillespie N (2016) Trust and team performance: A meta-analysis of main effects, moderators, and covariates. Journal of Applied Psychology 101(8): 113450.

De Linde Leonard M, Stanley TD and Doucouliagos H (2014) Does the UK minimum wage reduce employment? A meta-regression analysis. British Journal of Industrial Relations 52(3): 499-520.

Del Boca A, Kruse DL, and Pendleton A (1999) Decentralisation of bargaining systems and financial participation: A comparative analysis of Italy, UK and the US. Università degli studi di Brescia, Dipartimento di Scienze Economiche.

Dirks KT (1999) The effects of interpersonal trust on work group performance. Journal of Applied Psychology 84(3): 445-55.

Doucouliagos H (1995) Worker participation and productivity in labor-managed and participatory capitalist firms: A meta-analysis. Industrial and Labor Relations Review 49(1): 58-77.

Doucouliagos H and Laroche P (2003) What do unions do to productivity? A meta-analysis. Industrial Relations: A Journal of Economy and Society 42(4): 650-91.

Doucouliagos H and Laroche P (2013). Unions and innovation: New insights from the crosscountry evidence. Industrial Relations: A Journal of Economy and Society 52(2): 467-491.

Doucouliagos H, Freeman RB and Laroche P (2017) The Economics of Trade Unions: A Study of a Research Field and Its Findings. Oxon: Routledge.

Egger M, Smith GD, Schneider M and Minder C (1997) Bias in meta-analysis detected by a simple, graphical test. British Medical Journal 315: 629-34.

Eriksson T (2003) The effects of new work practices: Evidence from employer-employee data. The Determinants of the Incidence and the Effects of Participatory Organizations 7: 3-30.

Fehr E and Gachter S (2000) Fairness and retaliation: The economics of reciprocity. Journal of Economic Perspectives 14(3): 159-81.

Fernie S and Metcalf D (1995) Participation, contingent pay, representation and workplace performance: Evidence from Great Britain. British Journal of Industrial Relations 33(3): 379-415. 
Frey BS and Jegen R (2001) Motivation crowding theory. Journal of Economic Surveys 15(5): 589-611.

Freeman RB and Medoff JL (1984) What do Unions do? New York: Basic Books.

Freeman RB (2015) Workers Ownership and Profit-Sharing in a New Capitalist Model? Working Paper No. 267566, Harvard University \& Swedish Trade Union Confederation (LO) 2015.

Freeman, RB and Kleiner M (1990) The impact of new unionization on wages and working condition. Journal of Labor Economics 8(1): S8-S25.

Freeman RB, Kruse DL and Blasi JR (2010) Worker responses to shirking under shared capitalism. In Kruse DL, Freeman RB and Blasi JR (eds.), Shared Capitalism at Work: Employee Ownership, Profit and Gain Sharing, and Broad-based Stock Options. Chicago, IL: University of Chicago Press, pp. 77-104.

Gorodnichenko Y and Roland G (2011) Individualism, innovation, and long-run growth Proceedings of the National Academy of Sciences of the United States of America 108: 21316-19.

Hashi I and Hashani A (2013) Determinants of financial participation in the EU: Employers' and employees' perspective. In Kruse DL (ed.), Sharing Ownership, Profits, and Decisionmaking in the $21^{\text {st }}$ Century. Bingley, UK: Emerald Group, pp 187-216.

Hedges LV and Olkin I (1985) Statistical Methods for Meta-Analysis. London: Academic Press.

Heywood JS, Jirjahn U and Tsertsvadze G (2005) Getting along with colleagues-does profit sharing help or hurt? Kyklos 58(4): 557-73.

Hofstede G (1980) Culture's Consequences: International Differences in Work Related Values. Beverly Hills, CA: Sage Publications.

Hofstede G (2001) Culture's Consequences: Comparing Values, Behaviors, Institutions and Organizations Across Nations. ( $2^{\text {nd }}$ ed.). Thousand Oaks, CA: Sage Publications.

Hofstede G, Hofstede GJ and Minkov M (2010) Cultures and Organizations: Software of the Mind. New York: McGraw-Hill.

Jenkins GD, Gupta N, Mitra A and Shaw JD (1998) Are financial incentives related to performance? A meta-analytic review of empirical research. Journal of Applied Psychology 83(5): 777-87.

Johns G (2006) The essential impact of context on organizational behavior. Academy of Management Review 31(2): 386-408.

Jones DC and Kato T (1995) The productivity effects of employee stock-ownership plans and bonuses: Evidence from Japanese panel data. The American Economic Review 85(3): 391414.

Kahan DM (2003) The logic of reciprocity: Trust, collective action, and law. Michigan Law Review 102: 71-103.

Kato T and Morishima M (2002) The productivity effects of participatory employment practices: Evidence from new Japanese panel data. Industrial Relations: A Journal of Economy and Society 41(4): 487-520.

Kato T and Morishima M (2003) The nature, scope and effects of profit sharing in Japan: Evidence from new survey data. The International Journal of Human Resource Management 14(6): 942-55.

Kruse DL (1993) Profit Sharing: Does it Make a Difference? The Productivity and Stability Effects of Employee Profit-Sharing Plans. Kalamazoo, MI.:W.E. Upjohn Institute for Employment Research.

Kruse DL (1996) Why do firms adopt profit sharing and employee ownership plans? British Journal of Industrial Relations 34(4): 515-38. 
Kruse DL, Freeman RB, and Blasi JR (2010) Shared Capitalism at Work: Employee Ownership, Profit Sharing, Gainsharing, and Broad-based Stock Options. Chicago: University of Chicago Press.

Lin Z, Yao X and Zhao Z (2014) The direct and indirect impact of employee benefits on firm performance in China. Asia Pacific Journal of Human Resources 52(4): 476-95.

Marcus J and Le H. (2013) Interactive effects of levels of individualism-collectivism on cooperation: A meta-analysis. Journal of Organizational Behavior 34(6): 813-34.

McCarthy J, Voos P, Eaton A, Kruse DL and Blasi JR (2011) Solidarity and sharing: Unions and shared capitalism. In Carberry E (ed.), Employee Ownership and Shared Capitalism: New Directions in Research. Ithaca, NY: Cornell University Press.

National Civic Federation (1920) Profit Sharing by American Employers. New York: National Civic Federation.

O’Boyle E, Patel P and Gonzalez-Mulé E (forthcoming). Employee ownership and firm performance: A meta-analysis. Human Resource Management Journal, doi https://doiorg.proxy.libraries.rutgers.edu/10.1111/1748-8583.12115.

O'Halloran P (2013) Union coverage, membership and performance-related pay: Are piece rates different? National Institute Economic Review 226(1): R30-R41.

Ohkusa Y and Ohtake F (1997) The productivity effects of information sharing, profit sharing, and ESOPs. Journal of the Japanese and International Economies 11(3): 385-402.

Olson M (1965) Logic of Collective Action: Public Goods and Theory of Groups, Cambridge,

Massachusetts: Harvard University Press.

Pendleton A and Robinson A (2010) Employee stock ownership, involvement, and productivity: An interaction-based approach. Industrial and Labor Relations Review 64(1): 3-29.

Roth AE (1994) Lets keep the con out of experimental econ: A methodological note. Empirical Economics 19(2): 279-89.

Samuelson PA (1986) Thoughts on profit-sharing. Zeitschrift für die Gesamte Staatswissenschaft, Special Issue on Profit Sharing, A Symposium, Heinz Sauermann and Rudolf Richter (eds.). Tübingen: J.C.B. Mohr. In Crowley K (ed.), The Collected Scientific Papers of Paul A. Samuelson, Cambridge, Massachusetts: The MIT Press, pp. 953-62.

Schmidt FL and Hunter JE (2015) Methods of Meta-Analysis: Correcting Error and Bias in Research Findings, Third edition, Thousand Oaks: Sage.

Stanley TD (2001) Wheat from chaff: Meta-analysis as quantitative literature review. Journal of Economic Perspectives 15(3): 131-50.

Stanley TD (2005) Beyond publication bias. Journal of Economic Surveys 19(3): 309-47.

Stanley TD (2008) Meta-regression methods for detecting and estimating empirical effect in the presence of publication selection. Oxford Bulletin of Economics and Statistics 70(1): 103-27.

Stanley TD and Doucouliagos H (2012) Meta-Regression Analysis in Economics and Business. Oxford: Routledge.

Stanley TD and Doucouliagos H (2014) Meta-regression approximations to reduce publication selection bias. Research Synthesis Methods 5(1): 60-78.

Stanley TD and Doucouliagos H (2015) Neither fixed nor random: weighted least squares meta-analysis. Statistics in Medicine 34(13): 2116-27.

Stanley TD and Doucouliagos H (2017) Neither fixed nor random: weighted least squares meta-regression. Research Synthesis Methods 8(1): 19-42.

Stanley TD, Doucouliagos H, Giles M, Heckemeyer J, Johnston RJ, Laroche P, Pugh G, Nelson J, Paldam M, Poot J, Rosenberger R and Rost K (2013) Meta-analysis of economics research reporting guidelines. Journal of Economic Surveys 27(2): 390-94. 
Wagner JA III, Humphrey SE, Meyer CJ and Hollenbeck JR (2012) Individualismcollectivism and team member performance: Another look. Journal of Organizational Behavior 33(7): 946-63.

Weitzman ML and Kruse DL (1990) Profit-sharing and productivity. In Blinder AS (ed.), Paying for Productivity: A Look at the Evidence. Washington, D.C.: Brookings Institution, pp. 95-142.

Yao S (1995) Does profit-sharing work in a centrally-planned economy? Evidence from the Chinese state industries. Applied Economics Letters 2(4): 126-29.

Yao S (1997) Profit sharing, bonus payment, and productivity: A case study of Chinese stateowned enterprises. Journal of Comparative Economics 24(3): 281-96.

Zalusky J (1990) Labor-management relations: Unions view profit sharing. In Roomkin MJ, (ed.), Profit Sharing and Gain Sharing, Metuchen, NJ: Scarecrow Press, pp. 65-78. 


\section{APPENDIX}

\section{Studies included in the meta-analysis}

1. Addison JT, Schnabel C and Wagner J (2001) Works councils in Germany: Their effects on establishment performance. Oxford Economic Papers 53(4): 659-94.

2. Addison J, Siebert S, Wagner J and Wei X (2000) Worker participation and firm performance: Evidence from Germany and Britain. British Journal of Industrial Relations 38(1): 7-48.

3. Artus P, Legendre F and Morin P (1991) Le partage implicite des profits et ses effets sur la productivité du travail. Annales d'Economie et de Statistique, 33-57.

4. Bhattacherjee D (2005) The effects of group incentives in an Indian firm: Evidence from payroll data. Labour 19(1): 147-73.

5. Black SE and Lynch LM (2001) How to compete: The impact of workplace practices and information technology on productivity. Review of Economics and Statistics 83(3): 43445.

6. Boning B, Ichniowski C and Shaw K (1998). Incentive Pay for Production workers: An empirical analysis. mimeo, Columbia Business School.

7. Bryson A and Freeman R (2008) How does shared capitalism affect economic performance in the UK? (No. w14235). National Bureau of Economic Research.

8. Cable JR and Fitzroy FR (1980) Productive efficiency, incentives and employee participation: Some preliminary results for West Germany. Kyklos 33(1): 100-21.

9. Cable JR and Wilson N (1989) Profit-sharing and productivity: An analysis of UK engineering firms. Economic Journal 99(396): 366-75.

10. Cahuc P and Dormont B (1997) Profit-sharing: Does it increase productivity and employment? A theoretical model and empirical evidence on French micro data. Labour Economics 4(3): 293-319.

11. Cappelli P and Neumark D (2001) Do "high-performance" work practices improve establishment-level outcomes? Industrial and Labour Relations Review 54(4): 737-75.

12. Conte MA and Svejnar J (1988) Productivity effects of worker participation in management, profit-sharing, worker ownership of assets and unionization in US firms. International Journal of Industrial Organization 6(1): 139-51.

13. Conyon M and Freeman RB (2004) Shared modes of compensation and firm performance: UK evidence. In Card D, Blundell R and Freeman RB (eds.), Seeking a Premier Economy: The Economic Effects of British Economic Reforms, 1980-2000. University of Chicago Press, pp. 109-146.

14. Cooke WN (1994) Employee participation programs, group-based incentives, and company performance: A union-nonunion comparison. Industrial and Labour Relations Review 47(4): 594-609.

15. Defourney J, Estrin S and Jones DC (1985) The effects of workers' participation on enterprise performance: Empirical evidence from French cooperatives. International Journal of Industrial Organization 3(2): 197-217.

16. Drolet S, Lanoie P and Shearer BS (1999) Analyse de l'impact productif des pratiques de rémunération incitative pour une entreprise de services: Application à une coopérative financière québécoise. CIRANO Working Papers 99s-28.

17. Dunbar AE and Kumbhakar SC (1991) An empirical investigation of the association of productivity with employee stock ownership plans. The Journal of American Taxation Association, 22-38.

18. Estrin S, Jones DC and Svejnar J (1987) The productivity effects of worker participation: Producer cooperatives in Western economies. Journal of Comparative Economics 11(1): 40-61. 
19. Estrin S, Perotin V, Robinson A and Wilson N (1997) Profit-sharing in OECD Countries: A review and some evidence. London Business School Review 8(4): 27-32.

20. Fakhfakh F and Perotin V (2000) The effects of profit-sharing schemes on enterprise performance in France. Economic Analysis 3(2): 93-111.

21. *FitzRoy FR and Kraft K (1987) Cooperation, productivity, and profit sharing. The Quarterly Journal of Economics 102(1): 23-35.

22. *FitzRoy FR and Kraft K (1992) Forms of profit sharing and firm performance: Theoretical foundations and empirical problems. Kyklos 45(2): 209-25.

23. Gielen AC, Kerkhofs MJ and Van Ours JC (2010) How performance related pay affects productivity and employment. Journal of Population Economics 23(1): 291-301.

24. Han TS (2003) The economic effects of profit sharing and Taiwan-style employee stock ownership plans: Evidence from Taiwan's high-tech firms. Taiwan Academy of Management Journal 3(1): 1-22.

25. Hansen DG (1997) Worker performance and group incentives: A case study. Industrial and Labour Relations Review 51(1): 37-49.

26. Hübler O and Jirjahn U (2003) Works councils and collective bargaining in Germany: The impact on productivity and wages. Scottish Journal of Political Economy 50(4): 471-91.

27. Jirjahn U (2016) Performance pay and productivity: A note on the moderating role of a high-wage policy. Managerial and Decision Economics 37: 507-11.

28. Jones DC (2007) The productive efficiency of Italian producer cooperatives: Evidence from conventional and cooperative firms. Advances in the Economic Analysis of Participatory and Labor-Managed Firms,10: 3-28.

29. Jones DC (1993) The productivity effects of employee ownership within command economies: Evidence from Poland. Managerial and Decision Economics 14: 475-85.

30. Jones DC (1987) Productivity effects of worker directors and financial participation by employees in the firm: The case of British retail cooperatives. Industrial and Labour Relations Review 41: 79-92.

31. Jones DC and Kato T (1995). The productivity effects of employee stock-ownership plans and bonuses: evidence from Japanese panel data. The American Economic Review 85(3): 391-414.

32. Jones DC and Svejnar J (1985) Participation, profit sharing, worker ownership and efficiency in Italian producer cooperatives. Economica 52(208): 449-65.

33. Jones DC, Klinedinst M and Rock C (1998) Productive efficiency during transition: evidence from Bulgarian panel data. Journal of Comparative Economics 26(3): 446-64.

34. Kato T and Kodama N (2015) Performance-related pay and productivity: Evidence from Japan. RIETI Discussion Paper 15-E-088.

35. Kraft K (1991) The incentive effects of dismissals, efficiency wages, piece-rates and profitsharing. The Review of Economics and Statistics 73(3): 451-59.

36. Kato T, Lee JH and Ryu JS (2010) The productivity effects of profit sharing, employee ownership, stock option and team incentive plans: Evidence from Korean panel data. Advances in the Economic Analysis of Participatory and Labor-Managed Firms 11: 11135.

37. Kauhanen A and Piekkola H (2002) Profit sharing in Finland: Earnings and productivity effects (No. 817). ETLA Discussion Papers, The Research Institute of the Finnish Economy (ETLA).

38. Klos N (2006) Incentive Performance Related Pay and Productivity (Doctoral dissertation, National University).

39. Kruse DL (1992) Profit sharing and productivity: Microeconomic evidence from the United States. The Economic Journal 102(410): 24-36. 
40. Kruse DL (1993) Profit Sharing: Does it Make a Difference? The Productivity and Stability Effects of Employee Profit-Sharing Plans. Kalamazoo, MI.:W.E. Upjohn Institute for Employment Research.

41. Kumbhakar SC and Dunbar AE (1993) The elusive ESOP-productivity link: Evidence from US firm-level data. Journal of Public Economics 52(2): 273-83.

42. Lee MB and Rhee Y (1996) Bonuses, unions, and labor productivity in South Korea. Journal of Labor Research XVII(2): 219-38.

43. Long RJ and Fang T (2013) Profit sharing and workplace productivity: Does teamwork play a role? IZA Discussion Paper No. 7869.

44. Lucifora C and Origo F (2012) Performance related pay and firm productivity: New evidence from a quasi-natural experiment in Italy. IZA Discussion Paper No. 6483.

45. Ohkusa Y and Ohtake F (1997) The productivity effects of information sharing, profit sharing, and ESOPs. Journal of the Japanese and International Economies 11(3): 385-402.

46. Patibandla M and Chandra P (1998) Organizational practices and employee performance: the case of the Canadian primary textile industry. Journal of Economic Behavior and Organization 37(4): 431-42.

47. Perotin V and Robinson A (1998) Profit sharing and productivity: Evidence from Britain, France, Germany and Italy. Advances in the Economic Analysis of Participatory and Labor Managed Firms 6: 135-62.

48. Piekkola H (2005) Performance-related pay and firm performance in Finland. International Journal of Manpower 26(7/8): 619-35.

49. Pouliakas K and Theodoropoulos N (2009) Variety of performance pay and firm performance: Effect of financial incentives on worker absence and productivity. http://mpra.ub.uni-muenchen.de/18820/.

50. Moura Ramos L (2002) Profit sharing in Portugal: Why higher productivity? Labour 16(1): $157-75$.

51. Robinson AM and Wilson N (2006) Employee financial participation and productivity: An empirical reappraisal. British Journal of Industrial Relations 44(1): 31-50.

52. Robinson AM and Wilson N (2006). Financial participation and productivity: Insights from stochastic frontier estimation. Economic and Industrial Democracy 27(4): 609-35.

53. Schuster M (1983) Impact of union-management cooperation on productivity and employment. Industrial and Labour Relations Review 36(3): 415-30.

54. Schuster M (1984) The Scanlon plan: A longitudinal analysis. The Journal of Applied Behavioral Science 20(1): 23-38.

55. Shepard EM (1994) Profit sharing and productivity: Further evidence from the chemicals industry. Industrial Relations: A Journal of Economy and Society 33(4): 452-66.

56. Vaughan-Whitehead D (1998) Profit sharing in Albania: Boosting performance in a crisis economy. Advances in the Economic Analysis of Participatory and Labor Managed Firms, 6: 91-114.

57. Yao S (1997) Profit sharing, bonus payment, and productivity: A case study of Chinese state-owned enterprises. Journal of Comparative Economics 24(3): 281-96.

* These two studies are treated as a single study as they involve the same authors using the same data. 


\section{Preferred Reporting Items for Systematic Reviews and Meta-Analyses (PRISMA)}

Diagram

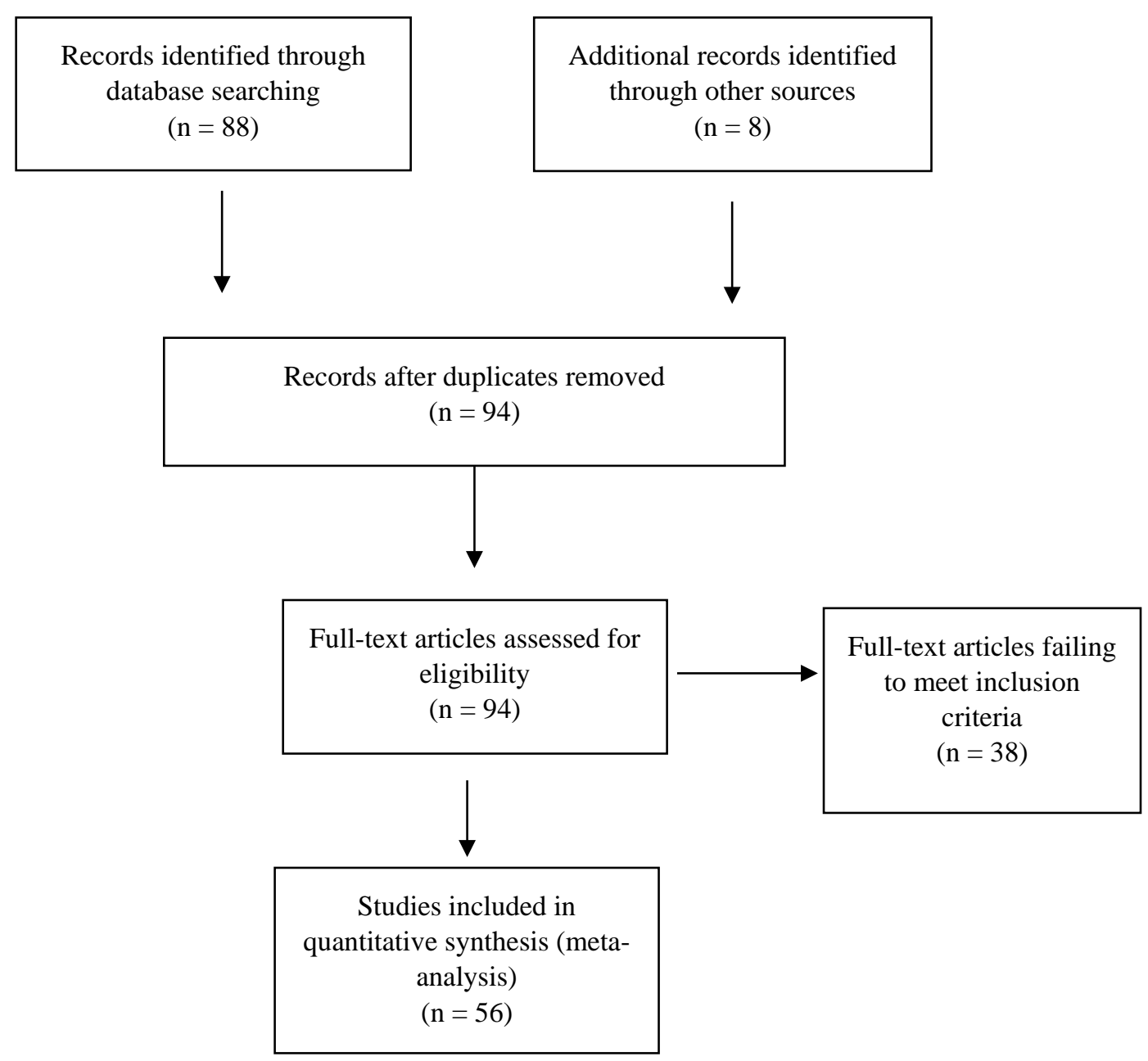


Table A1: Studies Excluded From the Meta-Analysis and Reasons for Exclusion

\section{Articles Journals/Outlet}

Examples of reviews and essays excluded; only empirical studies are included

Blanchflower \& Oswald (1987)

Jones \& Pliskin $(1988,1991)$

Weitzman \& Kruse (1990)

Kruse (1993)

Welbourne \& Meija (1995)

D’Art \& Turner (2001)

Urgakovic (2008)

Kruse et al. (2010)

Irish Journal of Management

Working papers

Book Chapter

NBER Working Paper

Journal of Management

The Irish Journal of Management

Book

Book

Examples of no quantifiable effect size available

Weiss (1987)

Bradley, Estrin \& Taylor (1990)

Kaufman (1992)

Bowie-McCoy, Wendt \& Chope (1993)

Krauter, Basso, \& Kimura (2004)

Blasi et al. (2008)

Kraft \& Lang (2016)

NBER Working Paper No 2194

Industrial Relations

Industrial and Labor Relations Review

Industrial Relations

Working Paper

NBER Working Paper

ILR Review

Examples of studies where productivity is not the dependent variable, e.g. we exclude studies that measure outcome as profitability, costs, wages, or employment

Hatcher \& Ross (1991)

Hubler (1993)

Journal of Organizational Behavior

Empirical Economics

Journal of Labor Economics

Knez \& Simester (2001)

Petersen \& Luthens (2006)

Long and Fang (2013)

Journal of Applied Psychology

Park \& Kruse (2014)

IZA Discussion Paper

Human Resource Management Journal

Examples of studies where effects of profit-sharing not identified (combined with other participatory practices or combined with individual incentive schemes)

Eriksson (2003)

Black \& Lynch (2004)

Kim (2005)

Hassan, Hagen, Daigs (2006)

Zwick (2006)

Wolf and Zwick (2008)

Roman (2009)

Origo (2009)

Damiani \& Ricci (2011)

Estimates included in other studies Yao (1995)

Examples of studies that use subjective measures of productivity

Blanchflower \& Oswald (1988)

Pendleton (1997)

Pendleton et al. (2002)

Pendleton et al. (2003)

D’Art \& Turner (2004)

Kalmi et al. (2005)

Poutsma et al. (2006)

Akthar et al. (2008)

Pendleton \& Robinson (2010)
Advances in the Economic Analysis of Part. \& LMF

The Economic Journal

Industrial and Labor Relations Review

Academy of Strategic Management Journal

Industrial Relations

SBR

Accounting, Organizations and Society

Labour Economics

Advances in the Economic Analysis of Part. \& LMF

Applied Economics Letters

The Economic Journal

Industrial Relations Journal

Transfer: European Review of Labour and Research

Advances in the Economic Analysis of Part. \& LMF

Personnel Review

Human Resource Management Journal

Economic and Industrial Democracy

Human Resource Management

Industrial and Labor Relations Review 
Table A2 reproduces Table 1 from the article, replacing partial correlations with the Fisher ztransformation. All the averages are essentially the same. However, as stated in the article, unconditional weighted averages do not allow heterogeneity and research design differences and are best treated as summary statistics.

Table A2. Profit sharing and productivity, unconditional weighted averages,

Fisher z-transformation

\begin{tabular}{|c|c|c|}
\hline Group/Country & $\begin{array}{c}\text { Number of } \\
\text { estimates [studies] } \\
\text { (1) }\end{array}$ & $\begin{array}{l}\text { Weighted average } \\
\text { partial correlation } \\
\text { (2) }\end{array}$ \\
\hline \multicolumn{3}{|c|}{ A: Cooperatives versus non-cooperatives } \\
\hline Cooperatives & 38 [6] & $0.266(0.130 ; 0.402)$ \\
\hline Non-cooperatives & $275[50]$ & $0.043(0.032 ; 0.054)$ \\
\hline \multicolumn{3}{|c|}{ B: Country differences (non-cooperatives) } \\
\hline USA & $80[13]$ & $0.036(0.021 ; 0.050)$ \\
\hline United Kingdom & $26[8]$ & $0.033(-0.034 ; 0.099)$ \\
\hline Germany & $26[8]$ & $0.116(0.051 ; 0.180)$ \\
\hline Other Europe: & $85[10]$ & $0.040(0.030 ; 0.051)$ \\
\hline - Italy & 27 [3] & $0.035(0.023 ; 0.048)$ \\
\hline - France & $22[4]$ & $0.040(0.005 ; 0.075)$ \\
\hline Asia: & $43[8]$ & $0.079(0.007 ; 0.151)$ \\
\hline - Japan & $27[3]$ & $0.078(-0.119 ; 0.275)$ \\
\hline Transition & $15[4]$ & $0.149(0.053 ; 0.246)$ \\
\hline
\end{tabular}

Notes: Column (1) reports the number of observations [and studies] used to calculate the weighted averages. Column (2) reports the weighted average partial correlation estimated with unrestricted weighted least squares using inverse variance weights. Figures in brackets in Column (2) are 95\% confidence intervals. Panel A compares cooperatives to non-cooperatives. Panel B reports country specific averages for non-cooperatives (participatory capitalist firms). See article for definition of Other Europe, Asia, and Transition. 
Table 3 in the article presents the key meta-regression results. Table A4 below presents the full meta-regression results. Column (6) presents the robustness of the results after removing any profit-based estimate.

Table A4: Profit sharing and Productivity, Meta-Regression Analysis, Full Results

\begin{tabular}{|c|c|c|c|c|c|c|}
\hline & $\begin{array}{c}(1) \\
\text { General }\end{array}$ & $\begin{array}{c}(2) \\
\text { General } \\
\text { with } \\
\text { values and } \\
\text { culture }\end{array}$ & $\begin{array}{c}\text { (3) } \\
\text { Specific } \\
\text { with } \\
\text { values and } \\
\text { culture }\end{array}$ & $\begin{array}{c}(4) \\
\text { Sample } \\
\text { size } \\
\text { weights }\end{array}$ & $\begin{array}{c}\text { (5) } \\
\text { Random } \\
\text { effects }\end{array}$ & $\begin{array}{c}(6) \\
\text { Excluding } \\
\text { dollar- } \\
\text { based } \\
\text { measures }\end{array}$ \\
\hline \multicolumn{7}{|c|}{ A: Meta-regressions } \\
\hline Constant & $\begin{array}{l}-0.003 \\
(-0.10)\end{array}$ & $\begin{array}{l}0.007 \\
(0.07)\end{array}$ & $\begin{array}{c}-0.082 \\
(-2.83)^{* * *}\end{array}$ & $\begin{array}{c}-0.071 \\
(-2.41)^{* *}\end{array}$ & $\begin{array}{c}-0.080 \\
(-2.20)^{* *}\end{array}$ & $\begin{array}{c}-0.073 \\
(-2.64)^{* *}\end{array}$ \\
\hline$S E$ & $\begin{array}{c}1.395 \\
(4.35)^{* * *}\end{array}$ & $\begin{array}{c}1.590 \\
(3.97)^{* * *}\end{array}$ & $\begin{array}{c}1.945 \\
(6.47)^{* * *}\end{array}$ & $\begin{array}{c}1.761 \\
(5.85)^{* * *}\end{array}$ & $\begin{array}{c}1.891 \\
(8.43)^{* * *}\end{array}$ & $\begin{array}{c}1.763 \\
(7.26)^{* * *}\end{array}$ \\
\hline Endogeneity & $\begin{array}{c}0.041 \\
(3.24)^{* * *}\end{array}$ & $\begin{array}{c}0.047 \\
(3.79)^{* * *}\end{array}$ & $\begin{array}{c}0.051 \\
(4.38)^{* * *}\end{array}$ & $\begin{array}{c}0.049 \\
(4.17)^{* * *}\end{array}$ & $\begin{array}{c}0.042 \\
(2.98)^{* * *}\end{array}$ & $\begin{array}{c}0.040 \\
(4.03)^{* * *}\end{array}$ \\
\hline Average year & $\begin{array}{l}-0.001 \\
(-0.89)\end{array}$ & $\begin{array}{l}-0.001 \\
(-0.73)\end{array}$ & - & - & - & - \\
\hline Number of firms & $\begin{array}{c}0.005 \\
(3.46)^{* * *}\end{array}$ & $\begin{array}{c}0.006 \\
(4.20)^{* * *}\end{array}$ & $\begin{array}{c}0.005 \\
(3.61)^{* * *}\end{array}$ & $\begin{array}{c}0.005 \\
(3.49)^{* * *}\end{array}$ & $\begin{array}{l}0.004 \\
(1.51)\end{array}$ & $\begin{array}{c}0.005 \\
(3.40)^{* * *}\end{array}$ \\
\hline Capital & $\begin{array}{l}-0.004 \\
(-0.30)\end{array}$ & $\begin{array}{l}0.009 \\
(0.51)\end{array}$ & $\begin{array}{c}0.028 \\
(3.03)^{* * *}\end{array}$ & $\begin{array}{c}0.029 \\
(3.08)^{* * *}\end{array}$ & $\begin{array}{c}0.022 \\
(1.74)^{*}\end{array}$ & $\begin{array}{c}0.019 \\
(2.01)^{*}\end{array}$ \\
\hline Time dummies & $\begin{array}{l}0.010 \\
(0.83)\end{array}$ & $\begin{array}{c}0.019 \\
(1.95)^{*}\end{array}$ & $\begin{array}{c}0.020 \\
(2.49)^{* *}\end{array}$ & $\begin{array}{c}0.017 \\
(2.24)^{* *}\end{array}$ & $\begin{array}{c}0.032 \\
(3.09)^{* * *}\end{array}$ & $\begin{array}{l}0.006 \\
(1.16)\end{array}$ \\
\hline Age & $\begin{array}{l}0.029 \\
(1.14)\end{array}$ & $\begin{array}{l}0.024 \\
(1.08)\end{array}$ & $\begin{array}{c}0.024 \\
(2.15)^{* *}\end{array}$ & $\begin{array}{c}0.024 \\
(2.12)^{* *}\end{array}$ & $\begin{array}{c}0.013 \\
(0.99)\end{array}$ & $\begin{array}{l}-0.007 \\
(-0.37)\end{array}$ \\
\hline Human capital & $\begin{array}{l}0.002 \\
(0.10)\end{array}$ & $\begin{array}{l}-0.022 \\
(-1.05)\end{array}$ & $\begin{array}{c}-0.016 \\
(-2.13)^{* *}\end{array}$ & $\begin{array}{c}-0.019 \\
(-2.30)^{* *}\end{array}$ & $\begin{array}{l}-0.002 \\
(-0.22)\end{array}$ & $\begin{array}{l}-0.010 \\
(-1.23)\end{array}$ \\
\hline Union density & - & $\begin{array}{c}0.099 \\
(2.31)^{* *}\end{array}$ & $\begin{array}{c}0.070 \\
(4.40)^{* * *}\end{array}$ & $\begin{array}{c}0.066 \\
(4.18)^{* * *}\end{array}$ & $\begin{array}{l}0.038 \\
(1.36)\end{array}$ & $\begin{array}{c}0.061 \\
(4.25)^{* * *}\end{array}$ \\
\hline Tax evasion & - & $\begin{array}{l}-0.002 \\
(-1.39)\end{array}$ & $\begin{array}{c}-0.002 \\
(-2.94)^{* * *}\end{array}$ & $\begin{array}{c}-0.002 \\
(-2.85) * * *\end{array}$ & $\begin{array}{c}-0.001 \\
(-2.07)^{* *}\end{array}$ & $\begin{array}{l}-0.001 \\
(-1.57)\end{array}$ \\
\hline Individualism & - & $\begin{array}{c}0.001 \\
(2.06)^{* *}\end{array}$ & $\begin{array}{c}0.001 \\
(4.87)^{* * *}\end{array}$ & $\begin{array}{c}0.001 \\
(4.46)^{* * *}\end{array}$ & $\begin{array}{c}0.001 \\
(3.18)^{* * *}\end{array}$ & $\begin{array}{c}0.001 \\
(3.56)^{* * *}\end{array}$ \\
\hline$U K$ & $\begin{array}{c}-0.0170 \\
(-0.46)\end{array}$ & $\begin{array}{c}-0.071 \\
(-2.10)^{* *}\end{array}$ & $\begin{array}{c}-0.070 \\
(-2.46)^{* *}\end{array}$ & $\begin{array}{c}-0.064 \\
(-2.20)^{* *}\end{array}$ & $\begin{array}{c}-0.064 \\
(-3.77)^{* * *}\end{array}$ & $\begin{array}{c}-0.054 \\
(-1.98)^{*}\end{array}$ \\
\hline Japan & $\begin{array}{l}0.009 \\
(0.43)\end{array}$ & $\begin{array}{l}0.054 \\
(1.47)\end{array}$ & $\begin{array}{c}0.091 \\
(4.37)^{* * *}\end{array}$ & $\begin{array}{c}0.090 \\
(4.02)^{* * *}\end{array}$ & $\begin{array}{c}0.097 \\
(3.67)^{* * *}\end{array}$ & $\begin{array}{c}0.061 \\
(2.44)^{* *}\end{array}$ \\
\hline Asia & $\begin{array}{l}0.005 \\
(0.15)\end{array}$ & $\begin{array}{c}0.093 \\
(1.95)^{*}\end{array}$ & $\begin{array}{c}0.125 \\
(4.29)^{* * *}\end{array}$ & $\begin{array}{c}0.118 \\
(3.89)^{* * *}\end{array}$ & $\begin{array}{c}0.108 \\
(2.70)^{* * *}\end{array}$ & $\begin{array}{c}0.115 \\
(3.44)^{* * *}\end{array}$ \\
\hline Transition & $\begin{array}{c}0.065 \\
(2.75)^{* * *}\end{array}$ & $\begin{array}{c}0.117 \\
(2.49)^{* *}\end{array}$ & $\begin{array}{c}0.165 \\
(5.58) * * *\end{array}$ & $\begin{array}{c}0.170 \\
(5.46)^{* * *}\end{array}$ & $\begin{array}{c}0.159 \\
(4.12)^{* * *}\end{array}$ & $\begin{array}{c}0.133 \\
(10.96)^{* * *}\end{array}$ \\
\hline Random effects & $\begin{array}{c}0.010 \\
(1.91)^{*}\end{array}$ & $\begin{array}{c}0.009 \\
(2.20)^{* *}\end{array}$ & $\begin{array}{c}0.018 \\
(1.70)^{*}\end{array}$ & $\begin{array}{c}0.018 \\
(1.73)^{*}\end{array}$ & $\begin{array}{c}0.021 \\
(1.77)^{*}\end{array}$ & $\begin{array}{c}0.019 \\
(1.77)^{*}\end{array}$ \\
\hline Canada & $\begin{array}{l}-0.014 \\
(-0.42)\end{array}$ & $\begin{array}{l}-0.008 \\
(-0.24)\end{array}$ & - & - & - & - \\
\hline Germany & $\begin{array}{l}0.022 \\
(0.65)\end{array}$ & $\begin{array}{l}-0.023 \\
(-0.47)\end{array}$ & - & - & - & - \\
\hline Other Europe & $\begin{array}{l}-0.007 \\
(-0.32)\end{array}$ & $\begin{array}{l}-0.034 \\
(-0.85)\end{array}$ & - & - & - & - \\
\hline Nonmanuf & $\begin{array}{l}0.005 \\
(0.67)\end{array}$ & $\begin{array}{l}0.001 \\
(0.18)\end{array}$ & - & - & - & - \\
\hline Continuous & $\begin{array}{l}0.019 \\
(1.11)\end{array}$ & $\begin{array}{l}0.014 \\
(0.90)\end{array}$ & - & - & - & - \\
\hline Salesbased & -.01222 & -0.016 & - & - & - & - \\
\hline
\end{tabular}




\begin{tabular}{|c|c|c|c|c|c|c|}
\hline & $(-1.44)$ & $(-1.45)$ & & & & \\
\hline Panel & $\begin{array}{l}0.032 \\
(1.54)\end{array}$ & $\begin{array}{l}0.022 \\
(1.07)\end{array}$ & - & - & - & - \\
\hline Decision & $\begin{array}{l}.00104 \\
(0.09)\end{array}$ & $\begin{array}{l}-0.002 \\
(-0.17)\end{array}$ & - & - & - & - \\
\hline Ownership & $\begin{array}{l}-0.011 \\
(-0.54)\end{array}$ & $\begin{array}{l}-0.008 \\
(-0.39)\end{array}$ & - & - & - & - \\
\hline Market share & $\begin{array}{c}-0.037 \\
(-1.78)^{*}\end{array}$ & $\begin{array}{l}-0.007 \\
(-0.28)\end{array}$ & - & - & - & - \\
\hline Unpublished & $\begin{array}{l}-0.013 \\
(-0.78)\end{array}$ & $\begin{array}{l}0.001 \\
(0.02)\end{array}$ & - & - & - & - \\
\hline Managerial & $\begin{array}{l}0.002 \\
(0.09)\end{array}$ & $\begin{array}{l}-0.003 \\
(-0.19)\end{array}$ & - & - & - & - \\
\hline Fixed effects & $\begin{array}{l}-0.016 \\
(-1.09)\end{array}$ & $\begin{array}{l}-0.023 \\
(-1.52)\end{array}$ & - & - & - & - \\
\hline $\mathrm{N}[\mathrm{k}]$ & 275 [50] & 267 [48] & 267 [48] & 267 [48] & 267 [48] & 209 [39] \\
\hline Adjusted $\mathrm{R}^{2}$ & 0.34 & 0.36 & 0.37 & 0.36 & - & 0.30 \\
\hline \multicolumn{7}{|c|}{$\begin{array}{l}\text { Notes: See Table } 2 \text { of the article for variable definitions and summary statistics. Column (1) reports the } \\
\text { general model including the full set of controls but excluding all contextual variables. Column (2) adds six } \\
\text { contextual variables: Union density, Tax evasion, and Individualism. Column (3) the reports the general-to- } \\
\text { specific MRA after removing all statistically insignificant variables. Columns (1) to (3) use weighted least } \\
\text { squares with inverse variance weights }\left(\mathrm{w}=1 / S E^{2}\right) \text {. Column (4) uses sample size weights, while Column ( } 5 \text { ) } \\
\text { uses random effect weights }\left(\mathrm{w}=1 /\left(S E^{2}+\tau^{2}\right) \text {, where } \tau^{2} \text { is the estimate of the between-study or heterogeneity }\right. \\
\text { variance. Column }(6) \text { removes all estimates that use a dollar-based measure of profit sharing to further reduce } \\
\text { impact of endogeneity. Brackets report } t \text {-statistics using standard errors adjusted for study-level clustering. } \\
*, * * \text {, and } * * * \text { denote statistical significance at the } 10 \%, 5 \% \text {, and } 1 \% \text { levels, respectively. }\end{array}$} \\
\hline
\end{tabular}

